\title{
LA CRISIS ASIÁTICA, SUS EFECTOS EN EL Y SU IMPACTO DE LA INCORPORACIÓ DEL PERÚ AL APEC
}

\author{
CARLOS AQUINO RODRÍGUEZ \\ E-mail: carlos-aquino@infoweb.com.pe \\ d21007@unmsm.edu.pe
}

La crisis asiática, que inicialmente afecto a algunos países de Asia que hasta ahora mostraban altas tasas de crecimiento económico como Indonesia, Tailandia y Corea del Sur, posteriormente se extendió a la mayoría de ellos, y ahora esta afectando a la economía mundial. Después de los efectos que tuvo en la economía rusa, ahora amenaza a Latinoamérica y a otros países, incluso a los países industrializados como los EE.UU.

Los efectos más visibles de la crisis asiática (que se ha convertido ya en una crisis económica mundial) son la baja en la demanda (y en el precio) por materias primas, presión hacia la devaluación de las monedas de los países emergentes, e inestabilidad en el mercado financiero internacional (como se ve en las bajas en las Bolsas de Valores en el mundo entero y la retracción de capitales hacia los mercados emergentes).

La crisis asiática puede afeetar el proceso de integración económica que persigue el APEC (Foro de Cooperación Económica Asia - Pacífico), al cual nuestro país se ha incorporado en noviembre de 1998. Como se sabe el gran atractivo de este foro es la creación de una área de libre comercio e inversiones para el año 2020 entre sus miembros, que son 21 desde noviembre con la incorporación oficial del Perú, Rusia y Vietnam.
En el presente trabajo vcremos en 3 partes el tema de la crisis asiática y su impacto en el Perú y cl APEC. Primero, trataremos de describir como y porque se inicio la crisis asiática; Segundo, que esta causando esto en cl Pcrú; y Tercero, como afectara esto al APEC, con una breve revisión de lo que es el APEC y lo que significa para el Perú.

\section{PRIMERA PARTE}

\section{¿Comó y por qué se inicio la crisis asiática?}

Lo que comenzó en julio de 1997 en Tailandia con la devaluación dc su moneda, se ha extendido por casi todos los países del Este Asiático generando una crisis económica en la mayoría de éstos y con repercusiones a nivel mundial. ¿Que realmente pasó en Asia?

Todo empezó con la devaluación de la moneda de Tailandia en julio de 1997. Esto se extendió a Malasia, Indonesia, Filipinas y luego Corea del Sur. Estos países han visto sus mouedas devaluadas en más del $50 \%$ de su valor desde julio de 1997 a octubre de este año 1998. Esto repercutió en sus Bolsas de Valores, que ya venían cayendo desde principios de 1997 y han perdido a la fecha mas del $60 \%$ de su valor (ver cuadro 1 ). 


\section{CUADRO 1}

\section{INDICADORES DE LA CRISIS ECONÓMICA EN EL ESTE ASIÁTICO}

\begin{tabular}{|c|c|c|c|c|c|}
\hline 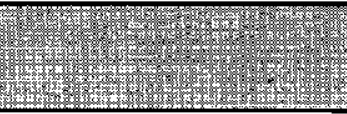 & Thisurita & Mratis & Thabnesta & Wilpinas & 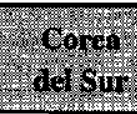 \\
\hline $\begin{array}{l}\text { - Déficit en cuenta } \\
\text { corriente como \% del } \\
\text { del PBI en 1996*: }\end{array}$ & 7.9 & 4.9 & 3.4 & 5.5 & 4.9 \\
\hline $\begin{array}{l}\text { - Valor de la Moneda, } \\
\text { por US\$: }\end{array}$ & baht & ringgit & пuрia & peso & won \\
\hline 1 de julio 1997 & 25.88 & 2.52 & 2,431 & 26.35 & 887.80 \\
\hline 23 de enero 1988 & 54.22 & 4.49 & 12,900 & 42.16 & 1,725 \\
\hline 05 de octubre de 1998 & 39.22 & 3.80 & 10,500 & 43.90 & 1,388 \\
\hline - Indice de la & & & & & \\
\hline $\begin{array}{l}\text { Bolsa de Valores: } \\
\text { al } 31 \text { de diciembre } 1996\end{array}$ & 831 & 1,237 & 637 & 3,170 & 651 \\
\hline al 1 de julio 1997 & 527 & 1,078 & 731 & 2,815 & 758 \\
\hline 23 de octubre 1997 & 500 & 650 & 500 & 2,000 & 520 \\
\hline 05 de octubre de 1998 & 246 & 360 & 261 & 1,166 & 308 \\
\hline $\begin{array}{l}\text { - Deuda extema } 1996 \\
\text { millones de US\$ } \\
\text { fines de año*: }\end{array}$ & 90,824 & 39,777 & 129,033 & 41,214 & 104,695 \\
\hline $\begin{array}{l}\text { - Reservas intemacionales } \\
\text { I996 millones de US\$ } \\
\text { fines de año*: }\end{array}$ & 37,731 & 27,009 & 17,820 & 9,902 & 33,237 \\
\hline
\end{tabular}

Fuente:* «Ajia Keizai 1998», Keizai Kikakucho, junio 1998, Japón.

Revista Semanal «Far Eastern Economic Review», Hong Kong,varios números.

¿Por qué sucedió esto?.

Tres factores se han señalado para que se desencadene la llamada crisis asiática:

1.- Las monedas de estos países habían estado casi pegadas al dólar, no habiéndose devaluado los últimos tres años hacia 1997 (excepto Indonesia), y así se habían sobrevaluado (y por eso sus exportaciones habían perdido competitividad, especialmente frente a China que había devaluado su moneda en enero de 1994), pero también frente a Japón pues sn moneda empezó a devaluarse desde abril de I995 (después de haberse revaluado ininterrumpidamente frente al dólar desde setiembre de 1985, ver cuadros 2 y 3 ). Esta revaluación de sus monedas hizo que sus exportaciones disminuyan su crecimiento, además estas habían empezado a disminuir en su crecimiento pues hubo una sobreproducción en ciertos productos que las compañías asiáticas fabricaban (ejem. microchips en Corea del Sur, sobrecapacidad en la producción de autos en la mayoría de los países de Asia, etc.). Esto se ve en los cuadros $4,5,6$ y 7 .

2.- Los países asiáticos en problemas tenían un 
CUADRO 2

TASA DE CAMBIO EN JAPÓN Y LOS 4 TIGRES

(unidades por US\$, promedio anual)

\begin{tabular}{|c|c|c|c|c|c|}
\hline & $\begin{array}{l}\text { Japón } \\
\text { (Yen) }\end{array}$ & $\begin{array}{l}\text { Corea del Sur } \\
\text { (won) }\end{array}$ & $\begin{array}{c}\text { Taiwán } \\
\text { (dólar taiw.) }\end{array}$ & $\begin{array}{l}\text { Hong Kong } \\
\text { (dólar H.K.) }\end{array}$ & $\begin{array}{c}\text { Singapur } \\
\text { (dólar Sing.) }\end{array}$ \\
\hline $\begin{array}{c}\text { Promedio } \\
1960 \text { 's }\end{array}$ & & & & & \\
\hline $\begin{array}{c}1960 \text { 's } \\
\text { Promedio }\end{array}$ & 360.0 & 203.5 & 40.0 & 5.8 & 3.1 \\
\hline 1970's & 286.9 & 427.3 & 38.2 & 5.2 & 2.6 \\
\hline $\begin{array}{l}\text { Promedio } \\
1980^{\prime} \mathrm{s}\end{array}$ & 198.9 & 757.8 & 35.6 & 7.0 & 2.1 \\
\hline Promedio & & & & & \\
\hline 1990 's & 117.9 & 794.4 & 26.8 & 7.7 & 1.6 \\
\hline 1960 & 360.0 & 63.1 & - & - & 3.1 \\
\hline 1965 & 360.0 & 266.4 & 40.0 & 5.7 & 3.1 \\
\hline 1966 & 360.0 & 271.3 & 40.0 & 5.7 & 3.1 \\
\hline 1967 & 360.0 & 270.5 & 40.0 & 6.1 & 3.1 \\
\hline 1968 & 360.0 & 276.6 & 40.0 & 6.1 & 3.1 \\
\hline 1969 & 360.0 & 288.2 & 40.0 & 6.1 & 3.1 \\
\hline 1970 & 360.0 & 310.6 & 40.0 & 6.1 & 3.1 \\
\hline 1971 & 350.7 & 347.2 & 40.0 & 6.0 & 3.1 \\
\hline 1972 & 303.2 & 392.9 & 40.0 & 5.6 & 2.8 \\
\hline 1973 & 271.7 & 398.3 & 37.9 & 5.1 & 2.4 \\
\hline 1974 & 292.1 & 404.5 & 38.0 & 5.0 & 2.4 \\
\hline 1975 & 296.8 & 484.0 & 38.0 & 4.9 & 2.3 \\
\hline 1976 & 296.6 & 484.0 & 38.0 & 4.9 & 2.4 \\
\hline 1977 & 268.5 & 484.0 & 38.0 & 4.6 & 2.4 \\
\hline 1978 & 210.4 & 484.0 & 36.0 & 4.6 & 2.2 \\
\hline 1979 & 219.1 & 484.0 & 36.0 & 5.0 & 2.1 \\
\hline 1980 & 226.7 & 607.4 & 36.0 & 4.9 & 2.1 \\
\hline [98] & 220.5 & 681.0 & 36.9 & 5.5 & 2.1 \\
\hline 1982 & 249.1 & 731.1 & 39.1 & 6.0 & 2.1 \\
\hline 1983 & 237.5 & 775.8 & 40.1 & 7.2 & 2.1 \\
\hline 1984 & 237.5 & 806.0 & 39.6 & 7.8 & 2.1 \\
\hline 1985 & 238.5 & 870.0 & 39.9 & 7.7 & 2.2 \\
\hline 1986 & 168.5 & 881.5 & 37.8 & 7.8 & 2.1 \\
\hline 1987 & 144.6 & 822.6 & 31.9 & 7.7 & 2.1 \\
\hline 1988 & 128.2 & 731.5 & 28.6 & 7.8 & 2.0 \\
\hline 1989 & 138.0 & 671.5 & 26.4 & 7.8 & 1.9 \\
\hline 1990 & 144.8 & 707.8 & 26.9 & 7.8 & 1.8 \\
\hline 1991 & 134.7 & 733.4 & 26.8 & 7.8 & 1.7 \\
\hline 1992 & 126.7 & 780.7 & 25.2 & 7.7 & 1.6 \\
\hline 1993 & 111.2 & 802.7 & 26.4 & 7.7 & 1.6 \\
\hline 1994 & 102.2 & 803.5 & 26.5 & 7.7 & 1.5 \\
\hline 1995 & 94.1 & 771.3 & 26.5 & 7.7 & 1.4 \\
\hline 1996 & 108.8 & 804.5 & 27.5 & 7.7 & 1.4 \\
\hline 1997 & 121.0 & 951.3 & 28.7 & 7.7 & 1.5 \\
\hline
\end{tabular}

Fuente: Keizai Kikakueho «Ajia Keizai 1998», Japón; en base a la información de los miśmos países. 
CUADRO 3

TASA DE CAMBIO EN LOS PAÍSES DE ASEAN Y CHWA (unidades por US\$, promedio anual)



Fuente: Keizai Kikakucho «Ajia Keizai 1998n, Japon; en basc a la información de los mismos países. 
CUADRO 4

EXPORTACIONES DE JAPÓN Y LOS 4 TIGRES

(Tasa de crecimiento anual)

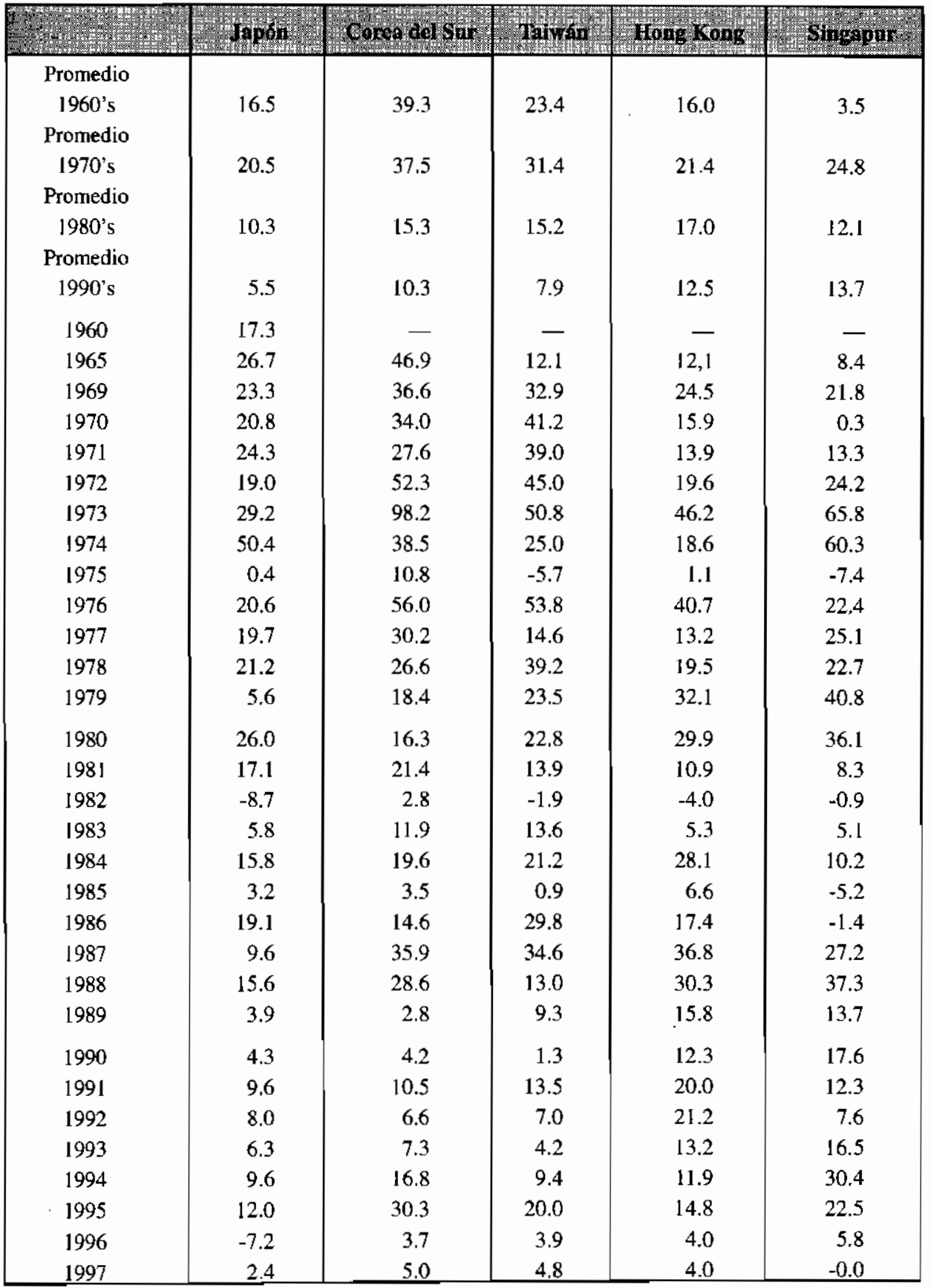

Fuente: Keizai Kikakucho «Ajia Keizai 1998», Japón; en base a la información de los mismos países. 


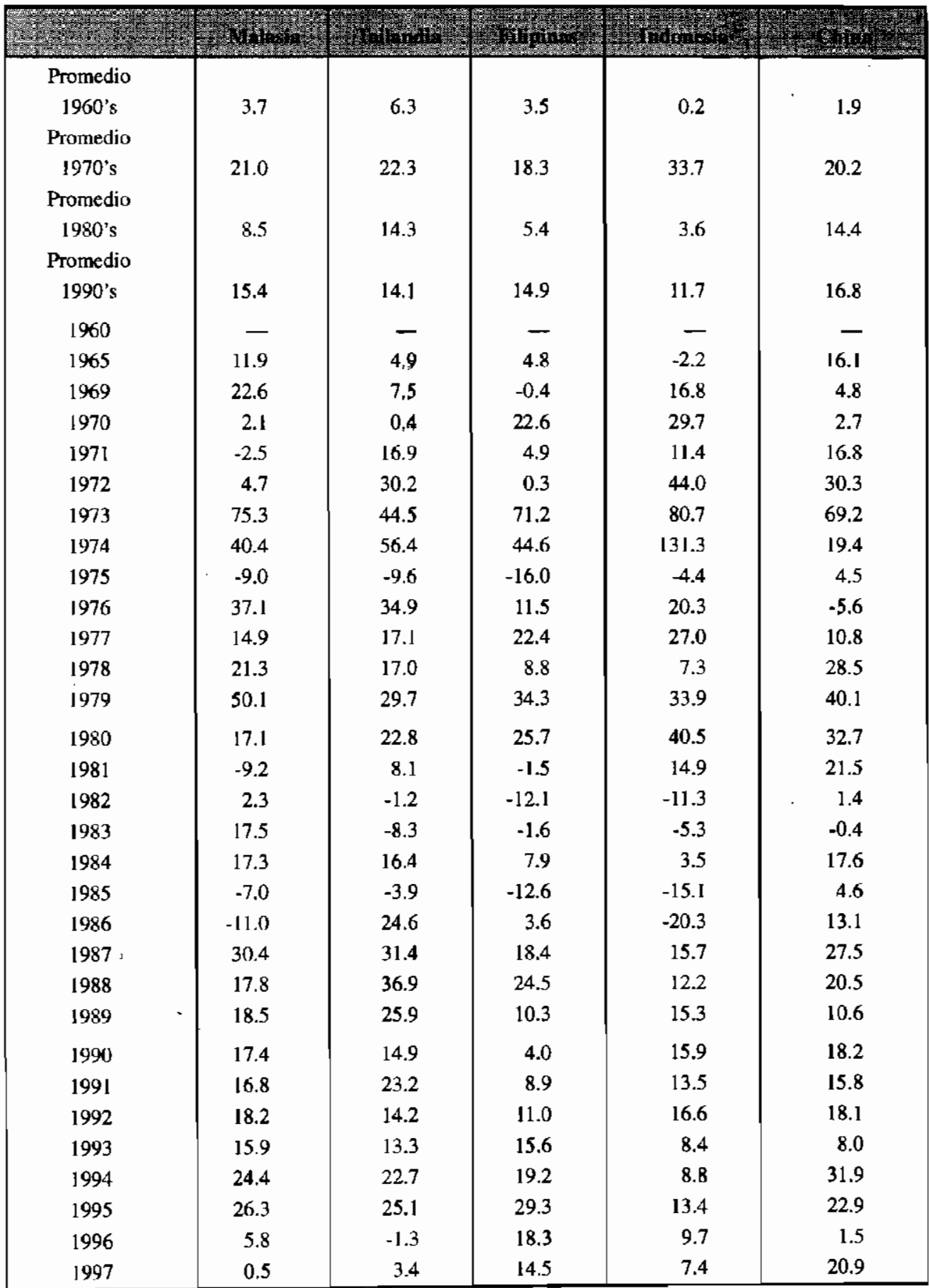

Fuente: Keizai Kikakucho «Ajia Keizai 1998», Japón; en base a la información de los mismos países. 
CUADRO 6

EXPORTACIONES DE JAPÓN Y LOS 4 TIGRES

(en millones de dólares FOB)

\begin{tabular}{|c|c|c|c|c|c|}
\hline 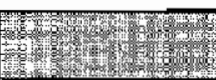 & 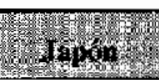 & entarasom & Triwhen & Hongroust &  \\
\hline Promedio & & & & & \\
\hline 1960 's & 8.296 & 216 & 516 & 1,312 & 1,142 \\
\hline Promedio & & & & & \\
\hline 1970 's & 56,960 & 6,170 & 6,863 & 7,064 & 5,947 \\
\hline Promedio & & & & & \\
\hline 1980's & 189,498 & 34,958 & 37,078 & 36,339 & 26,489 \\
\hline Ptomedio & & & & & \\
\hline $1990^{\circ} \mathrm{s}$ & 371,599 & 97,838 & 93,822 & 141,182 & 89,193 \\
\hline 1960 & 4,055 & 32 & - & - & 1,136 \\
\hline 1965 & 8,451 & 173 & 448 & 1,138 & 981 \\
\hline 1969 & 15,990 & 624 & 1,050 & 2,178 & 1.549 \\
\hline 1970 & 19,317 & 836 & 1,483 & 2,525 & 1,554 \\
\hline 1971 & 23,995 & 1.067 & 2,060 & 2,876 & 1,761 \\
\hline 1972 & 29,088 & 1,625 & 2,988 & 3,440 & 2,186 \\
\hline 1973 & 37,017 & 3,221 & 4,504 & 5,029 & 3,625 \\
\hline 1974 & 55,469 & 4,462 & 5,631 & 5,964 & 5,809 \\
\hline 1975 & 55,819 & 4,945 & 5,310 & 6,032 & 5,380 \\
\hline 1976 & 67,304 & 7,716 & 8,166 & 8,490 & 6,583 \\
\hline 1977 & 81,083 & 10,048 & 9,360 & 9,614 & 8,236 \\
\hline 1978 & $98,21]$ & 12.722 & 13.032 & 11.493 & 10,108 \\
\hline 1979 & 102,299 & 15,057 & 16,101 & 15,180 & 14,228 \\
\hline 1980 & 130,441 & 17,512 & 19,772 & 19,719 & 19,359 \\
\hline 1981 & 151,459 & 21,268 & 22,518 & 21,860 & 20,964 \\
\hline 1982 & 138,385 & 21,853 & 22,094 & 20,988 & 20,782 \\
\hline 1983 & 146,965 & 24,446 & 25,091 & 22,105 & 21,842 \\
\hline 1984 & 169,700 & 29,245 & 30,422 & 28,312 & 24,068 \\
\hline 1985 & 177,164 & 30,282 & 30,690 & 30,193 & 22,807 \\
\hline 1986 & 210,757 & 34,715 & 39,826 & 35,449 & 22,807 \\
\hline 1987 & 231,256 & 47,182 & 53,614 & 48,524 & 28,616 \\
\hline 1988 & 264,856 & 60,696 & 60,574 & 63,137 & 39,282 \\
\hline 1989 & 275,175 & 62,377 & 66,179 & 73,141 & 44,669 \\
\hline 1990 & 286,948 & 65,016 & 67,044 & 82,144 & 52,527 \\
\hline 1991 & 314,525 & 71,870 & 72,487 & 98,571 & 58,972 \\
\hline 1992 & 339.650 & 76,632 & 81,395 & 119,496 & 63,444 \\
\hline 1993 & 360,911 & 82,236 & 84,668 & 135,356 & 73,942 \\
\hline 1994 & 395,600 & 96,013 & 93.050 & 151,398 & 96,457 \\
\hline 1995 & 442,937 & 125,058 & 111,364 & 173.754 & 118,185 \\
\hline 1996 & 411,209 & 129,715 & 115,690 & 180,750 & 125,012 \\
\hline 1997 & 421,010 & 136,164 & 121,300 & 188,059 & 125,008 \\
\hline
\end{tabular}

Fuente: Keizai Kikakucho «Ajia Keizai 1998», Japón; en base a la mformación de los mismos países. 
EXPORTACIONES DE LOS PAÍSES DE ASEAN Y CHINA (en millones de dólares FOB)

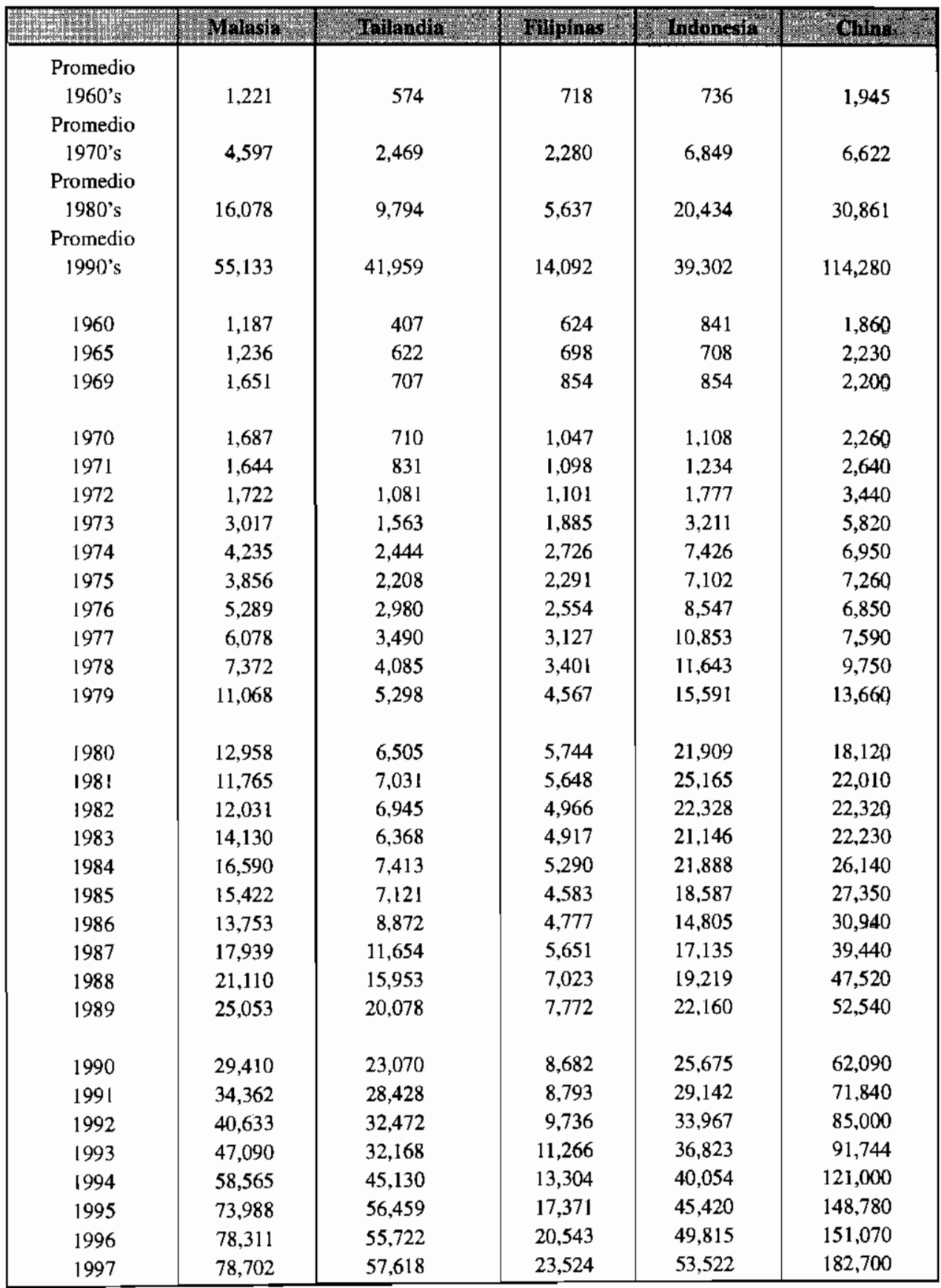

Fuente: Keizai Kikakucho «Ajia Keizai 1998», Japón; en base a la información de los mismos paŕses. 
déficit en cuenta corriente bastante grande, especialmente Tailandia uno de los mas afectados con un déficit de casj $8 \%$ de su Producto Bruto Interno (PBI) en 1996. En promedio los países mas afectados tenían un déficit en cuenta corriente de $4 \%$ a $5 \%$ del PBI. (ver cuadros $8,9,10$ y 11 )

El déficit en cuenta corriente aumento en los últimos años en los países asiáticos mas afectados por la crisis por dos razones: primero, algunos de ellos como Corea del Sur y Tailandia aumentaron su déficit comercial e Indonesia disminuyó su superávit comercial, pues sus exportaciones no crecieron al mismo ritmo que sus importaciones (ver cuadros 12 y 13); y segundo todos los países asiáticos aumentaron su deuda externa desde 1990 y con ello aumentaron el servicio (intereses) de esta deuda que tenían que pagar (ver cuadros 14 al 17).

Los casos de Corea del Sur y Tailandia, países que prácticamente triplicaron el valor de su deuda externa entre los años 1990 a 1997, es ilustrativo de esto. Indonesia también incremento grandemente su deuda entre estos años, y no es casualidad entonces que justamente estos 3 países son Ios que mayor problemas tienen ahora.

3.- Por último el sistema financiero en estos países tenía muchas deudas por cobrar por prestamos mal hechos, incobrables, a empresas que se expandieron sin ningún control y con poco criterio técnico (parte importante de los préstamos para estas inversiones se hizo con prestamos del extcrior, asumiendo deudas a corto plazo, ver cuadro 18).

El gran problema de Asia es su sistema financiero. Sin poca supervisión del gobierno, protegido de la competencia extranjera, con una tasa de cambio fija para su moneda y bajas tasas de interés en casa, se prestaron dólares del exterior para financiar proyectos en casa, muchos de ellos con poco criterio técnico, que llevo a la sobreproducción en algunos ítems, aparte que en algunos países como Tailandia se invirtió ese dinero en especulación en la compra de acciones en
Bolsa y en terrenos (propiedad inmobiliaria). Es impresionante como rápidamente incrementaron sus deudas con el exterior varios países de Asia en los primeros años del 90 (ver otra vez cuadros 14 y 15). El caso ya mencionado de Corea del Sur, Tailandia e Indonesia, los 3 países mas afectados por la crisis es ilustrativo. Pero to peor es que mucha de esta deuda se contrató a corto plazo, pagadera a menos de un año (ver cuadro 18).

Cuando a comienzos de 1997 las Bolsas de Valores en varios países de Asia empezaron a bajar (ver cuadro 1), los precios de los terrenos también ya habían empezado a bajar, y los ingresos por exportaeiones ya estaban disminuyendo o estancándose en el último año (cuadros 6 y 7 ). Frente a esta situación de falta o disminución de ingresos de empresas (y familias), los bancos no pueden cobrar sus prestamos mal hechos, la situación económica se deteriora, y las monedas sobrevaluadas comienzan a sufrir presión a la devaluación. Frente a esto los gobiernos no quieren devaluar sus monedas pues muchas deudas de sus empresas y bancos estaban en dólares y una devaluación brusca llevaría a la quiebra a muchas de ellas. Los gobiernos salen entonces a defender el valor de su moneda vendiendo dólares en el mercado y comprando sus monedas. Esta acción de los Bancos Centrales lo que hace mas bien es terminar con las Reservas Internacionales de países como Tailandia, que a comienzos del año 1997 tenía mas de 35,000 millones de dólares en Reservas Internacionales (ver cuadro 1), pero que al 2 de julio de 1997 , cuando termina la defensa de su moneda el baht y devalúa su moneda, se había quedado con sólo 5,000 millones de dólares en Reservas Internacionales.

Lo anterior fue agravada por la acción de algunos especuladores internacionales que apostaron ya desde comienzos del año 1997 por la devaluación de las monedas asiáticas, y esto agudiza la caída de estas. Además los países asiáticos en problemas experimenta- 
ron una corrida de capitales espectacular en el año 1997 (ver cuadro 19). Según este cuadro, cn 1996 entraron a los 5 países mas afectados por la crisis, como Corea del Sur, Tailandia, Indonesia, Malasia y Filipinas, 96.1 millones de dolares, pero en 1997 hubo un saldo negativo de -11.9 mil millones de dólares. Esto cs, de 1996 a 1997 hubo una salida de capitales de casi 110 millones de dólares $\{96.1 \mathrm{mil}$ millones mas $11.9 \mathrm{mil} \mathrm{mi-}$ lones), de estos 5 países. Esto demuestra la volatilidad del capital intemacional que saca su dinero de un país o una región tan rápido como lo deposita en otro país o región.

Al quedarse a partir de julio de 1997 varios países del Asia sin Reservas Internacionales al defender inútilmente su moneda de una devaluación, y al salir los capitales internacionales de estos con tanta rapidez, varios de ellos se quedan sin fondos para cubrir sus obligaciones externas, y por eso se ven obligados especialmente Tailandia, Indonesia y Corea del Sur, a pedir ayuda al Fondo Monetario lutemacional (FMI).

\section{¿Hasta cuándo la crisis asiática?}

Las recetas dadas por el FMI han sido motivo de discusión pues para algunos han agravada la crisis. Fundamentalmente el FMI pidió: Primero, que los países corten sus gastos para tener un superávit fiscal, pero todos estos países ya tenían superávit fiscal antes, además el problema no era por el lado del gobierno que no tenía deudas sino por el lado privado (ver cuadro 20). Esto para algunos agravo la recesión económica en estos países pues el recorte innecesario del gasto del gobiemo hizo que la economía se recese aun más.

Segundo, el FMI para defender el valor de las monedas de estos paises que se devaluaban en picada, pidió que se eleven las tasas de interés que cobraban los bancos. Esto corto efectivamente el crédi to a muchas empresas, paralizando la producción y agravaudo otra vez Ja recesión económica en estos países.

En todo caso las consecuencias de las crisis asiá- tica son severas en la mayoría de los países de la región y se espera que esta crisis pueda durar mas de 2 años, esperándose que a partir del año 2000 se puedan recuperar. (ver cuadro 21).

\section{SEGUNDA PARTE}

\section{La Crisis Asiática y sus efectos en el Perú}

La crisis asiática, que se ha extendido por todo el mundo en estos momentos, esta afectando a todos los países, a unos menos que otros, pero si la crisis se agudiza, definitivamente el golpe será fuerte para todos. El Perú ya está sufriendo los efectos de esta crisis y con algunos países latinoamericanos en problemas, al parecer la crisis puede afectarnọs aun más.

El presente capitulo ṣe dividirá en 3 partes y una conclusión. Primera, se verá cómo la crisis asiática eš́a afectando ya al Perú; Segundo, que medidas se puede tomar para enfrentar esta crisis; y finalmente cuales son las perspectivas de que la crisis se prolongue o agrave mas de lo que está.

\section{A.- Cómo la crisis asiática está afectando a la economía del Perú.}

La crisis financiera que empezo en Asia, en Tailandia en julio de 1997 con la devaluación de su moneda, se ha extendido a nivel mundial y esta afectando la economía de todos los países. El Perí ha sido ya afectado $y$ esto se manifiesta en las cifras macroeconómicas.

La crisis financiera y económica que empezó en Asia ya ha dejado de ser crisis asiática para transformarse en un fenómeno mundial. La crisis se transmite al Perú en 3 áreas:

1.- El menor crecimiento económico de Asia, y de la economía mundial, sígnifica menores ingresos por nuestras exportaciones, que son mayormente materias primas. En promedio, el 70\% de las exportaciones peruanas son marerias primas (en 1996 el $71.4 \%$ y en 1997 el $68.8 \%$ de 
CUADRO 8

BALANZA EN CUENTA CORRIENTE EN JAPÓN Y LOS 4 TIGRES

(millones de dólares)

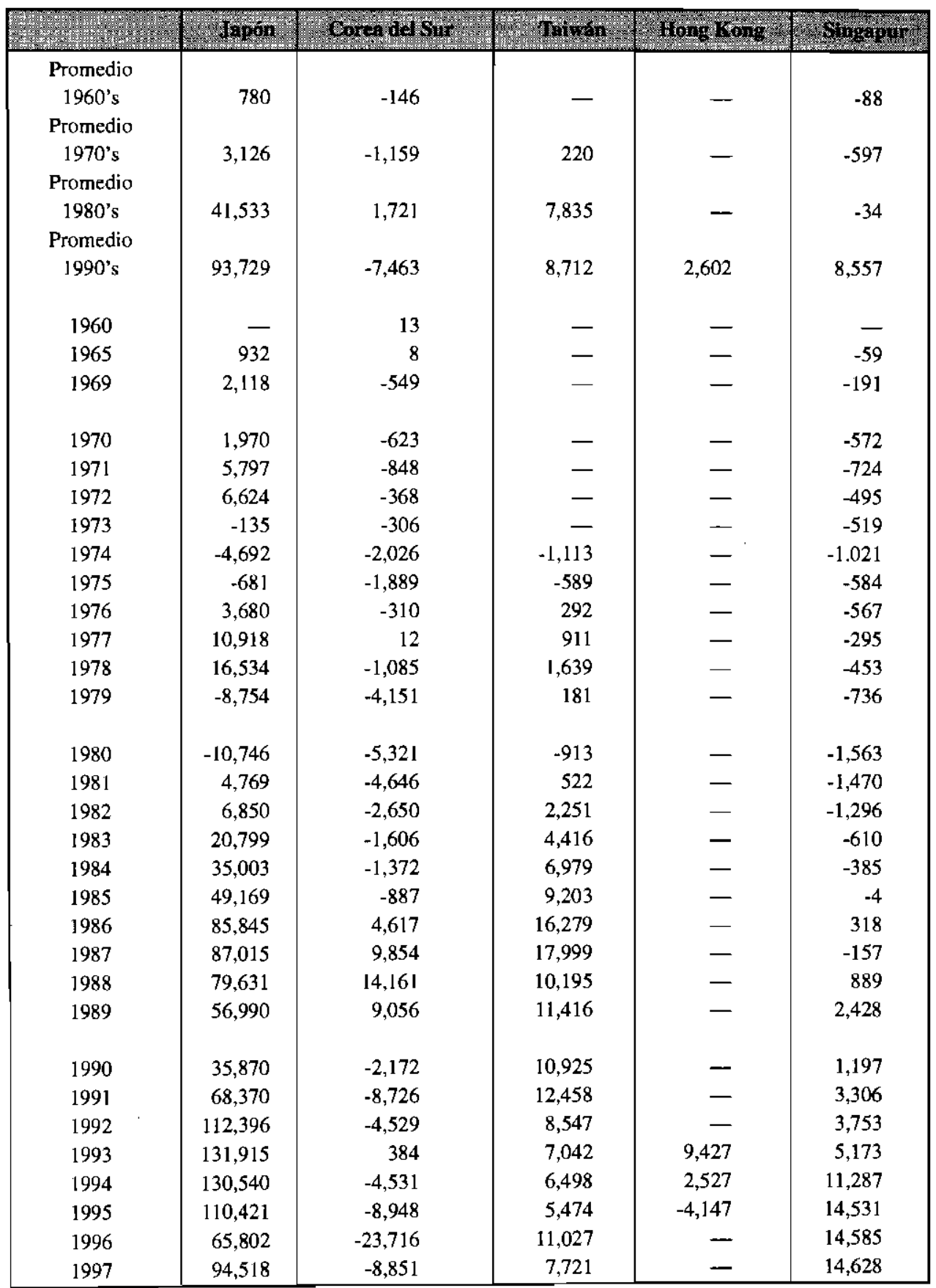

Fuente: Keizai Kikakucho «Ajia Keizai 1998», Japón; en base a la información de los mismos países. 
CUADRO 9

BALANZA EN CUENTA CORRIENTE EN LOS PAÍSES DE ASEAN Y CHINA (millones de dólares)

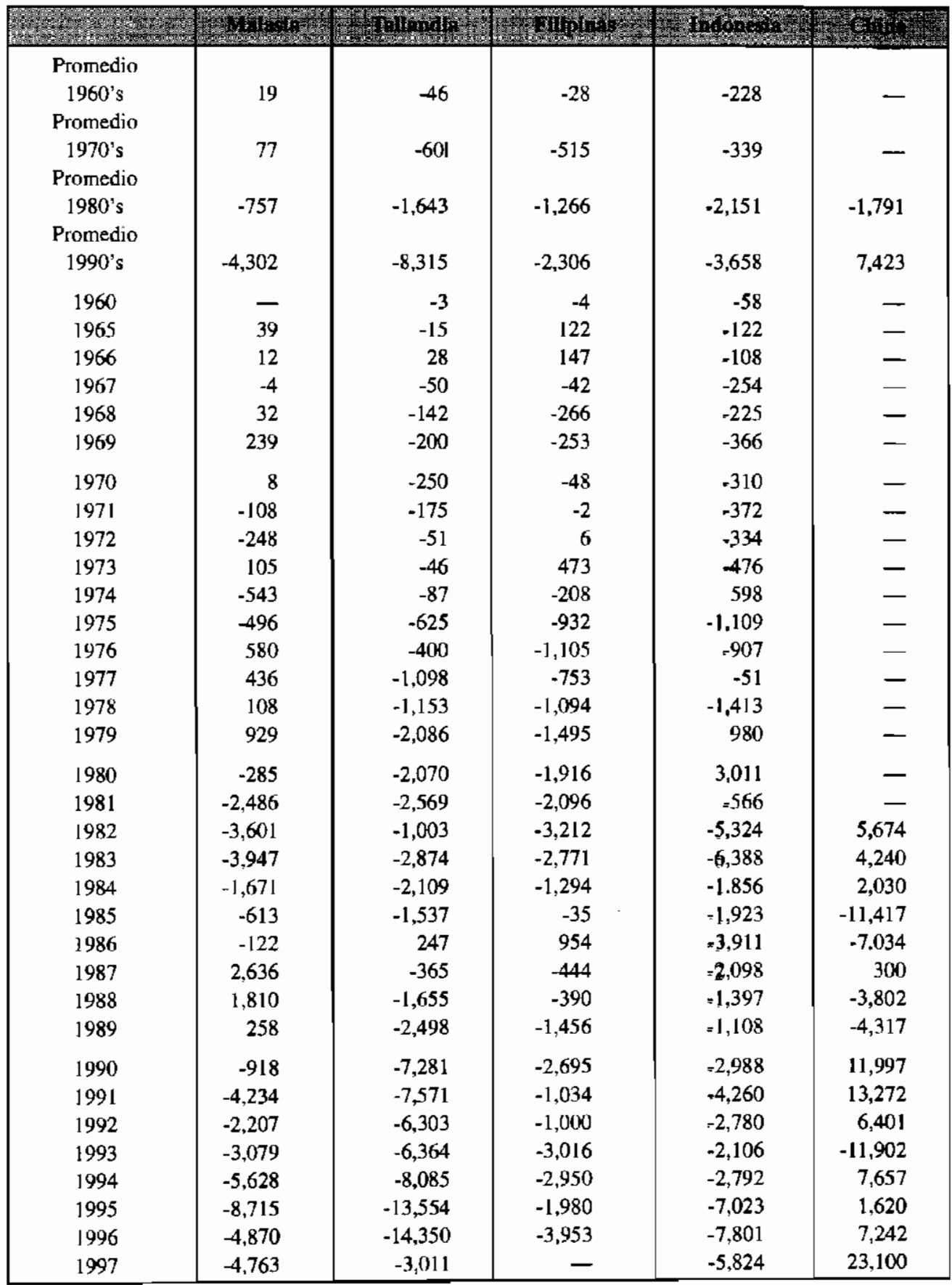

Fuente: Keizai Kikakucho «Ajia Kcizai 1998», Japón; en base a la información de los mismos países. 
CUADRO 10

BALANZA EN CUENTA CORRIENTE EN JAPÓN Y LOS 4 TIGRES

(como porcentaje del PBI)

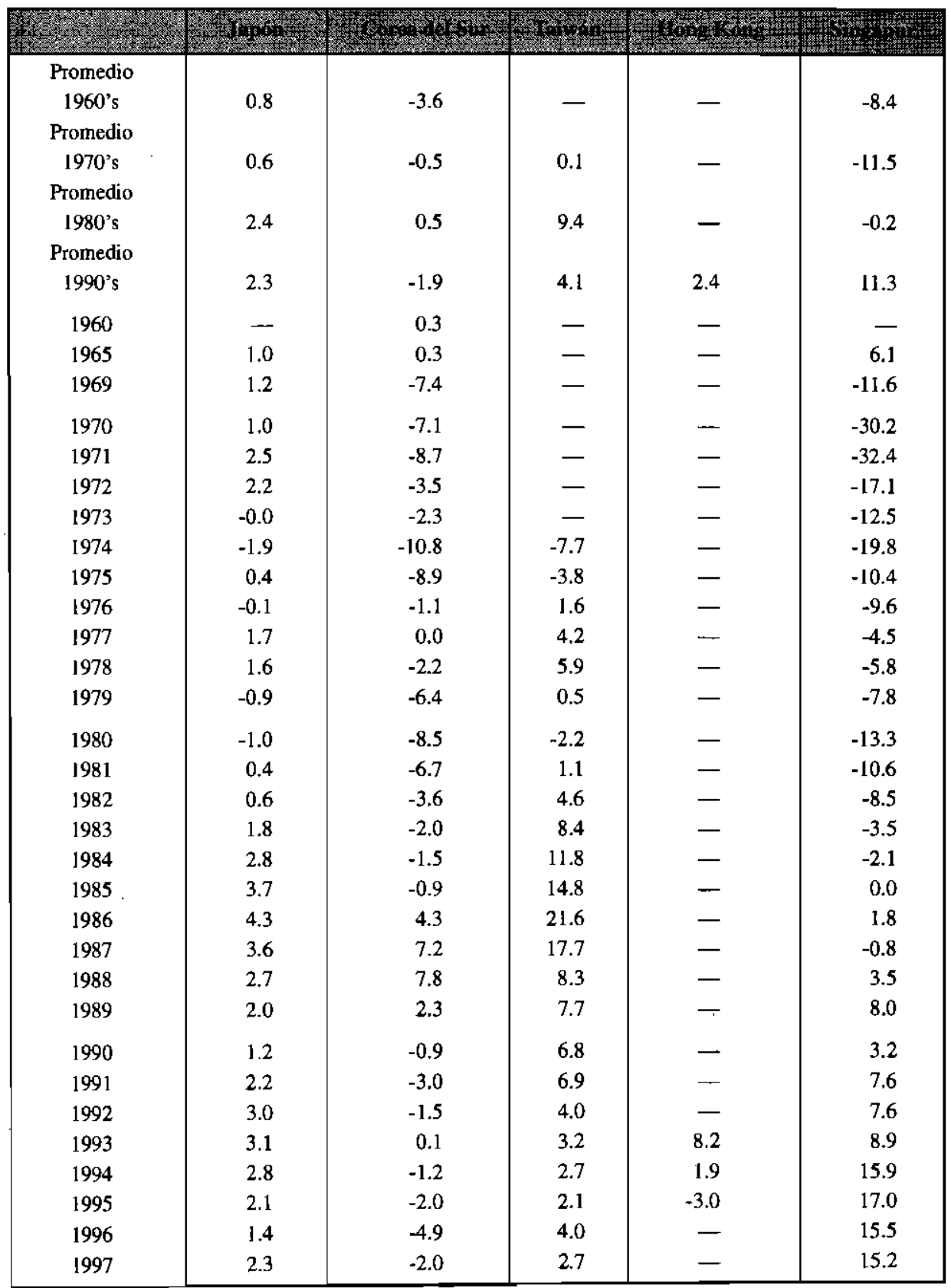

Fuente: Keizai Kikakucho «Ajia Keizai 1998», Japón; en base a la información de los mismos paŕses. 
CUADRO 11

BALANZA EN CUENTA CORRIENTE EN LOS PAfSES DE ASEAN Y CHINA (como porcentaje del PBI)

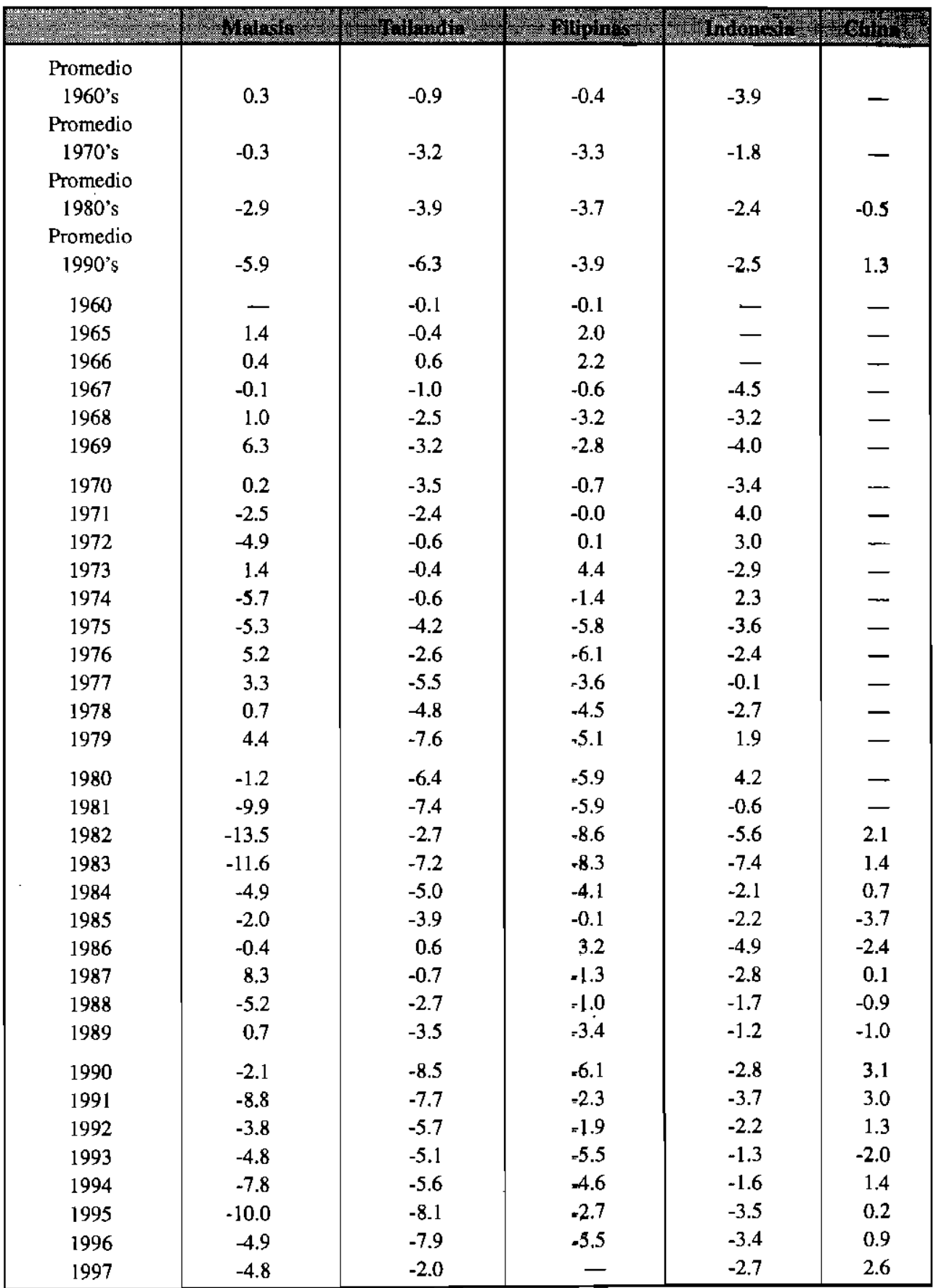

Fuente: Keizai Kikakucho «Ajia Keizai 1998», Japón; en base a la información de los mismos países. 
CUADRO 12

BALANZA COMERCIAL DE JAPON Y LOS 4 TIGRES

(millones de US\$)

\begin{tabular}{|c|c|c|c|c|c|}
\hline  & t. & 7 Coma a d sur & Taritur & Vong Ring & 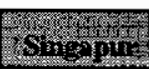 \\
\hline $\begin{array}{c}\text { Promedio } \\
1960 \text { 's }\end{array}$ & -501 & -535 & -104 & -381 & -277 \\
\hline Promedio & & & & & \\
\hline 1970 's & 2,247 & $-1,846$ & 363 & -857 & $-2,101$ \\
\hline Promedio & & & & & \\
\hline 1980's & 41,050 & 306 & 8,720 & -953 & $-4,942$ \\
\hline Promedio & & & & & \\
\hline 1990's & 91,119 & $-8,333$ & 9,720 & $-9,639$ & $-7,653$ \\
\hline 1960 & -436 & -312 & - & - & -197 \\
\hline 1965 & 282 & -290 & -108 & -426 & -262 \\
\hline 1966 & 253 & -465 & -88 & -444 & -226 \\
\hline 1967 & $-1,221$ & -675 & -167 & -275 & -299 \\
\hline 1968 & -16 & $-1,006$ & -116 & -314 & -389 \\
\hline 1969 & 966 & $-1,200$ & -166 & -280 & -491 \\
\hline 1970 & 436 & $-1,148$ & -46 & -391 & -908 \\
\hline 1971 & 4,307 & $-1,327$ & 212 & -517 & -1.077 \\
\hline 1972 & 5,120 & -897 & 468 & -419 & $-1,205$ \\
\hline 1973 & $-1,383$ & $-1,019$ & 677 & -583 & $-1,467$ \\
\hline 1974 & $-6,575$ & $-2,390$ & $-1,362$ & -812 & $-2,565$ \\
\hline 1975 & $-2,110$ & $-2,329$ & -658 & -737 & $-2,746$ \\
\hline 1976 & 2,427 & $-1,058$ & 547 & -354 & $-2,485$ \\
\hline 1977 & 9,686 & -763 & 827 & -830 & $-2,226$ \\
\hline 1978 & 18,200 & $-2,250$ & 1,673 & $-1,951$ & $-2,922$ \\
\hline 1979 & $-7,641$ & $-5,282$ & 1,289 & $-1,980$ & $-3,408$ \\
\hline 1980 & $-10,721$ & $-4,780$ & 21 & $-2,620$ & $-4,625$ \\
\hline 1981 & 8,741 & $-4,863$ & 1,387 & $-2,900$ & $-6,607$ \\
\hline 1982 & 6,900 & $-2,398$ & 3,276 & $-2,554$ & $-7,370$ \\
\hline 1983 & 20,534 & $-1,746$ & 4,780 & $-2,028$ & $-6,317$ \\
\hline 1984 & 33,611 & $-1,386$ & 8,430 & -247 & $-4,591$ \\
\hline 1985 & 46,099 & -854 & 10,569 & 480 & $-3,472$ \\
\hline 1986 & 83,743 & 3,130 & 15,592 & 74 & $-3,011$ \\
\hline 1987 & 79,706 & 6,163 & 18,642 & 11 & $-3,870$ \\
\hline 1988 & 77,563 & 8,885 & 10,797 & -734 & -4.560 \\
\hline 1989 & 64,328 & 912 & 13,710 & 985 & -4.998 \\
\hline 1990 & 52,149 & $-4,828$ & 12,309 & -314 & $-8,055$ \\
\hline 1991 & 77,789 & $-9,655$ & 13,053 & $-1,678$ & $-7,128$ \\
\hline 1992 & 106,628 & $-5,143$ & 9,176 & $-3,918$ & $-8,704$ \\
\hline 1993 & 120,241 & $-1,564$ & 7,742 & $-3,410$ & $-11,219$ \\
\hline 1994 & 120,858 & $-6,335$ & 7,346 & $-10,437$ & $-5,938$ \\
\hline 1995 & 106,843 & $-10,062$ & 7,805 & $-19,001$ & $-6,207$ \\
\hline 1996 & 61,941 & $-20,624$ & 13,166 & $-17,800$ & $-6,320$ \\
\hline 1997 & 82,501 & $-8,452$ & 7,163 & $-20,555$ & $-7,404$ \\
\hline
\end{tabular}

Fuente: Keizai Kikakucho «Ajia Keizai 1998», Japón; en base a la información de los mismos países. 


\section{CUADRO 13}

BALANZA COMERCIAL DE LOS PAÍSES DE ASEAN Y CHINA

(en millones de US\$)



Fuente: Keizai Kikakucho «Ajia Keizai 1998», Japón; en base a la información de los mismos páses. 


\section{CUADRO 14}

\section{DEUDA EXTERNA TOTAL DE JAPÓN Y LOS 4 TIGRES}

(saldo a fin de año, millones de US\$)

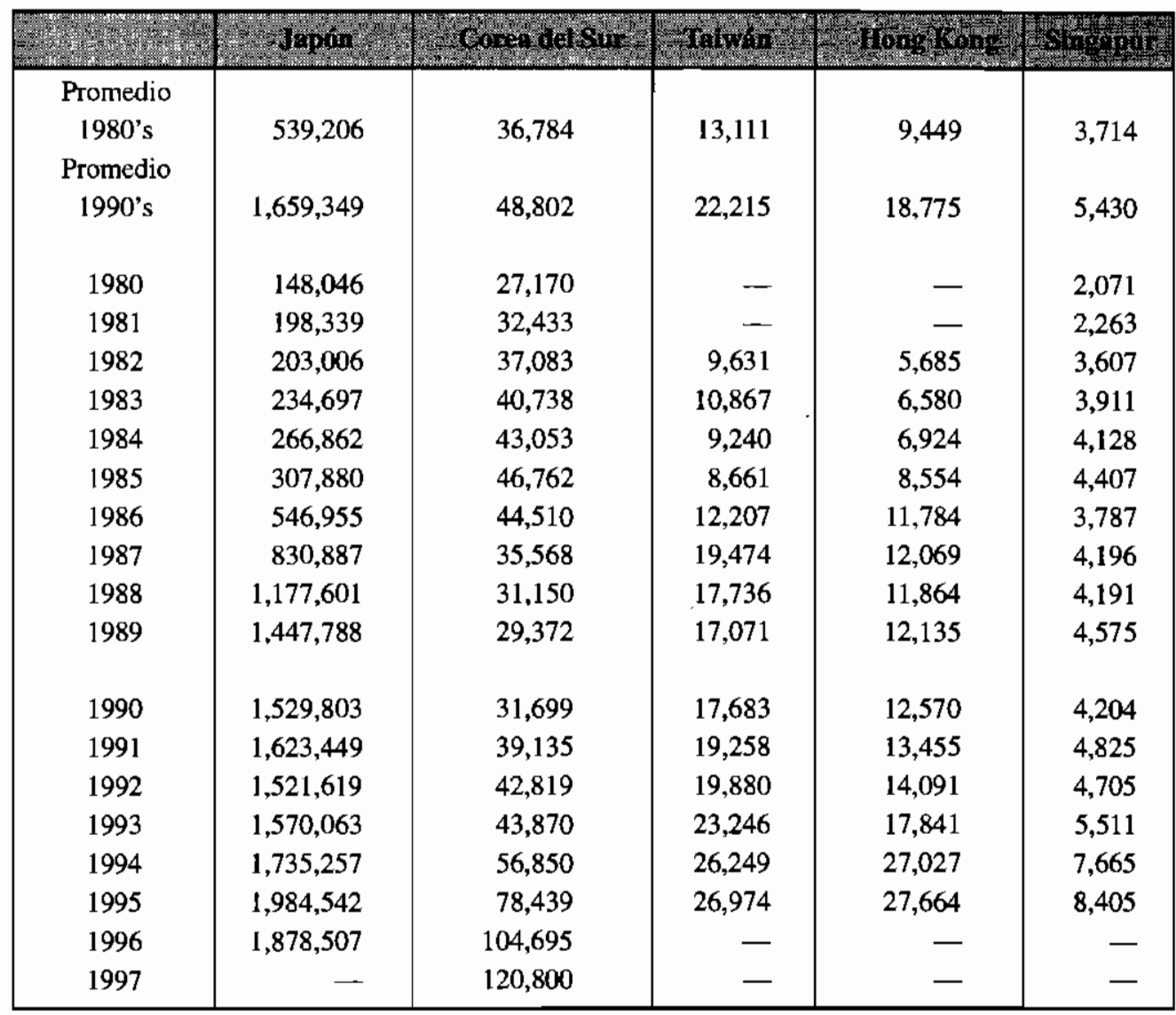

Fuente: Keizai Kikakucho «Ajia Keizai 1998», Japón; en base a la información de los mismos países. 


\section{CUADRO 15}

\section{DEUDA EXTERNA TOTAL DE LOS PAÍSES DE ASEAN Y CHINA}

(saldo a fin de año, millones de US\$)

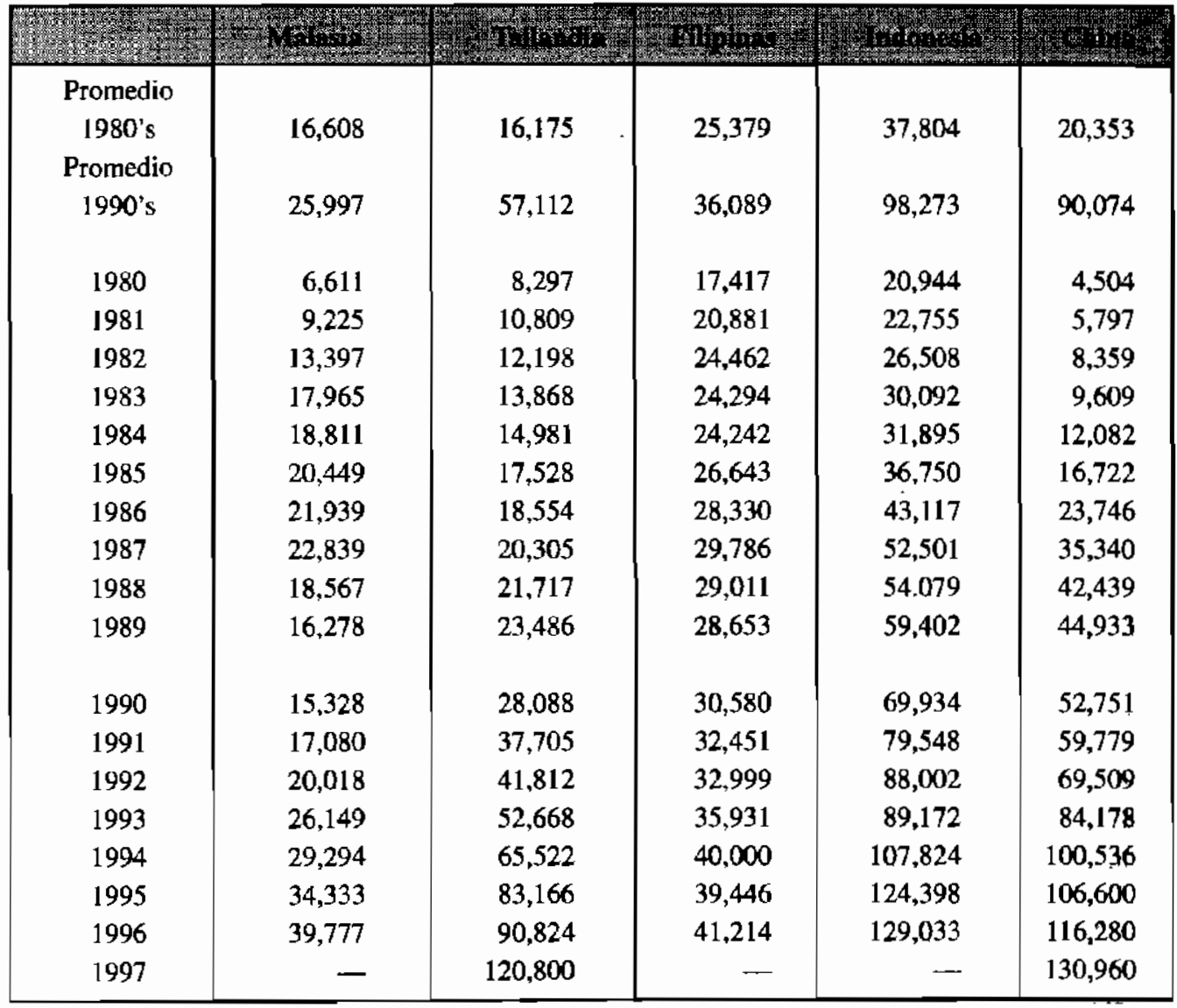

Fuente: Keizai Kikakucho «Ajia Keizai 1998», Japón; en base a la información de los mismos países. 
CUADRO 16

DEUDA EXTERNA TOTAL DE JAPÓN Y LOS 4 TIGRES

(como porcentaje del PBI)

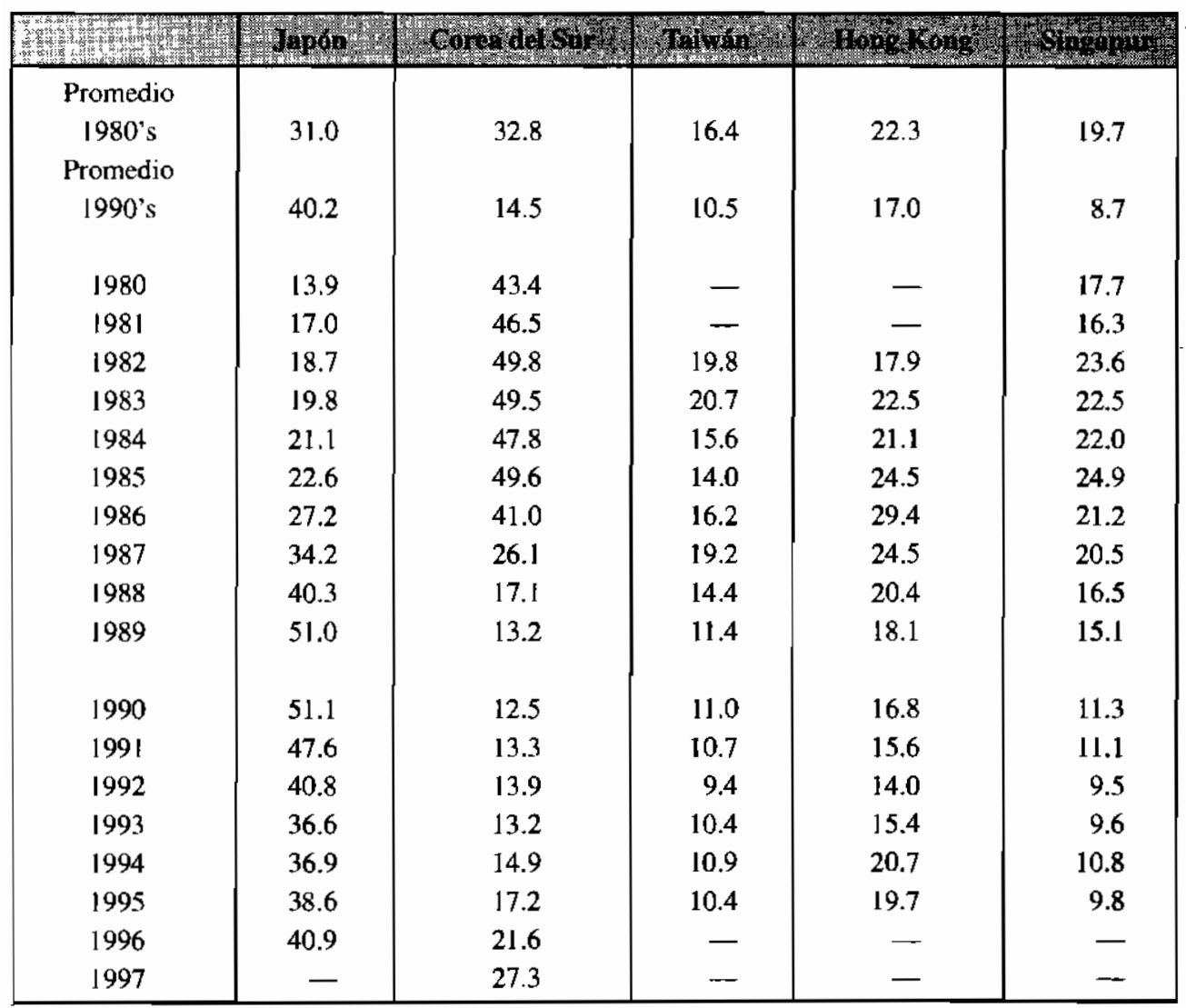

Fuente: Keizai Kikakucho «Ajia Keizai 1998», Japón; en base a la información de los mismos países. 
CUADRO 17

DEUDA EXTERNA TOTAL DE LOS PAÍSES DE ASEAN Y CHINA (como porcentaje del PBI)

\begin{tabular}{|c|c|c|c|c|c|}
\hline 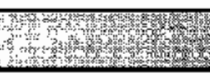 & Why & Hownol & W11, & 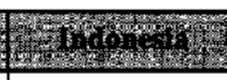 & 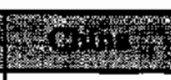 \\
\hline Promedio & & & & & \\
\hline I980's & 54.2 & 35.6 & 73.8 & 44.3 & 5,9 \\
\hline Promedio & & & & & \\
\hline 1990's & 38.0 & 42.3 & 58.9 & 59.9 & 14.9 \\
\hline 1980 & 27.0 & 25.6 & 53.7 & 28.9 & 1.5 \\
\hline 1981 & 36.9 & 31.0 & 58.6 & 24.7 & 2.1 \\
\hline 1982 & 50.0 & 33.3 & 65.9 & 28.1 & 3.1 \\
\hline 1983 & 59.6 & 34.6 & 73.1 & 35.2 & 3.3 \\
\hline 1984 & 55.4 & 35.8 & 77.2 & 36.4 & 3.9 \\
\hline 1985 & 65.5 & 45.0 & 86.7 & 42.1 & 5.5 \\
\hline 1986 & 79.1 & 43.1 & 94.8 & 53.9 & 8.0 \\
\hline 1987 & 72.3 & 40.2 & 89.7 & 69.1 & 11.0 \\
\hline 1988 & 53.5 & 35.1 & 76.6 & 64.2 & 10.6 \\
\hline 1989 & 43.0 & 32.5 & 67.5 & 62.9 & 10.0 \\
\hline 1990 & 35.8 & 32.9 & 69.1 & 65.9 & 13.6 \\
\hline 1991 & 35.5 & 38.4 & 71.4 & 68.2 & 14.7 \\
\hline 1992 & 34.3 & 37.5 & 62.3 & 68.7 & 14.4 \\
\hline 1993 & 40.7 & 42.1 & 66.1 & 56.4 & 14.0 \\
\hline 1994 & 40.4 & 45.4 & 62.4 & 61.0 & 18.6 \\
\hline 1995 & 39.3 & 49.5 & 5.3 .2 & 61.5 & 15.3 \\
\hline 1996 & 40.1 & 50.1 & 71.8 & 56.7 & 14.3 \\
\hline 1997 & - & - & - & - & 14.5 \\
\hline
\end{tabular}

Fuente: Keizai Kikakucho «Ajia Keizai 1998», Japón; en base a la información de los mismos países. 


\section{CUADRO 18}

\section{ESTRUCTURA DE LA DEUDA EXTERNA DE LOS PAÍSES ASIÁTICOS}

([ines de 1996)

\begin{tabular}{|c|c|c|c|c|}
\hline 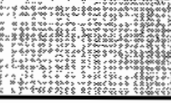 & 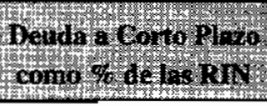 & 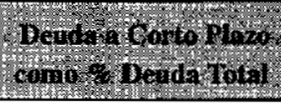 &  & Whon \\
\hline Tailandia & 169 & 65 & 50.1 & 6.3 \\
\hline Indonesia & 181 & 61 & 56.7 & 5.0 \\
\hline Filipinas & 77 & 58 & 71.8 & 3.7 \\
\hline Malasia & 47 & 50 & 40.1 & 4.1 \\
\hline Corea def Sur & 213 & 67 & 21.6 & 2.7 \\
\hline China & 36 & 49 & 14.3 & 9.1 \\
\hline Perút & 63 & 9.8 & 43.7 & 14.2 \\
\hline
\end{tabular}

- Deudas hacia los bancos que reportan al Bank of Intemational Settlements

Fuente: Bank of International Setrlements

Tomado de «What eaused the Asian currency and financial

Crisis «, de Corserte, Pesente and Rubini, marzo de 1998.

Página Web: www.stem.nyu.edu/ nroubini/asia/AsiaHomepage.html.

* Keizai Kikakucho «Ajia Keizai 1998», Japón; en base a la información de los mismos países.

* RIN: Reservas Intemacionales Netas

* M: Importaciones

+ datos del Perú para fines de 1997, de la Nota Semanal No. 38, del 9-10-98, Banco Central de Reserva del Perú

\section{CUADRO 19}

FLUJO DE CAPITALES PRIVADOS HACIA COREA DEL SUR, INDONESIA, TAILANDIA, MALASIA Y FILIPINAS

(miles de millones de dólares)

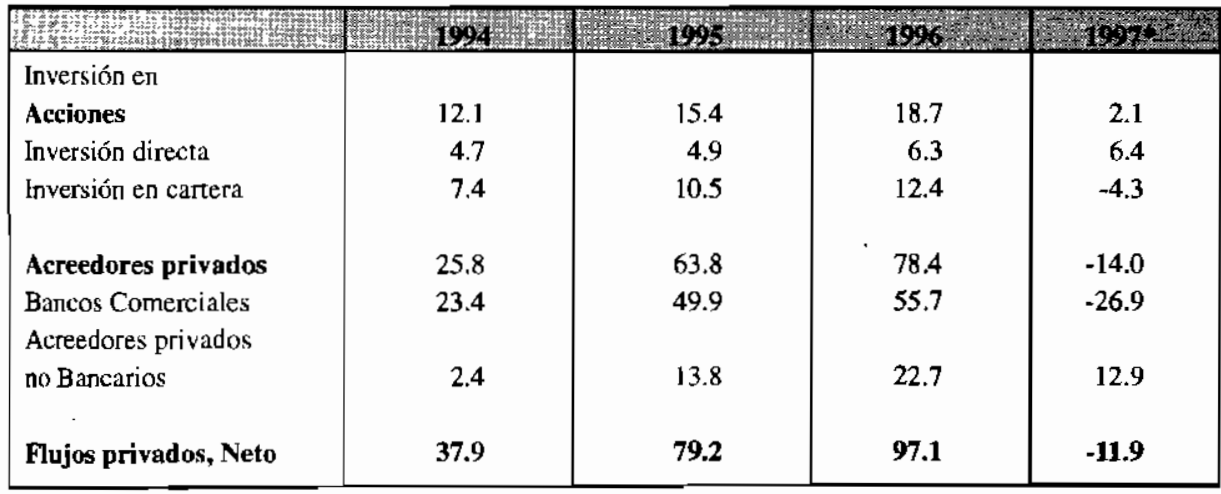

* Estimado

Fuente: Institute of International Finance

tomado de la revista semanal «Far Eastern Economic Review», del 16 de julio de 1998, Hong Kong. 


\section{CUADRO 20}

\section{INDICADORES DE LOS PAÍSES DEL ESTE ASIÁTICO 1996}

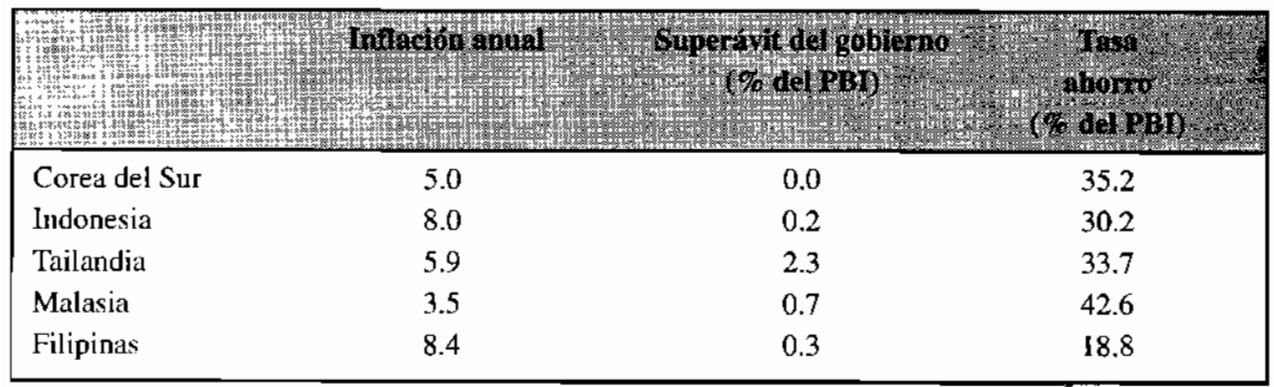

Fuente: «Ajia Keizai 1998» de Keizai Kikakucho, Tokio, junio de 1998.

\section{CUADRO 2I}

\section{PRINCIPALES INDICADORES DE LOS PAÍSES DEL ESTE ASIÁTICO}

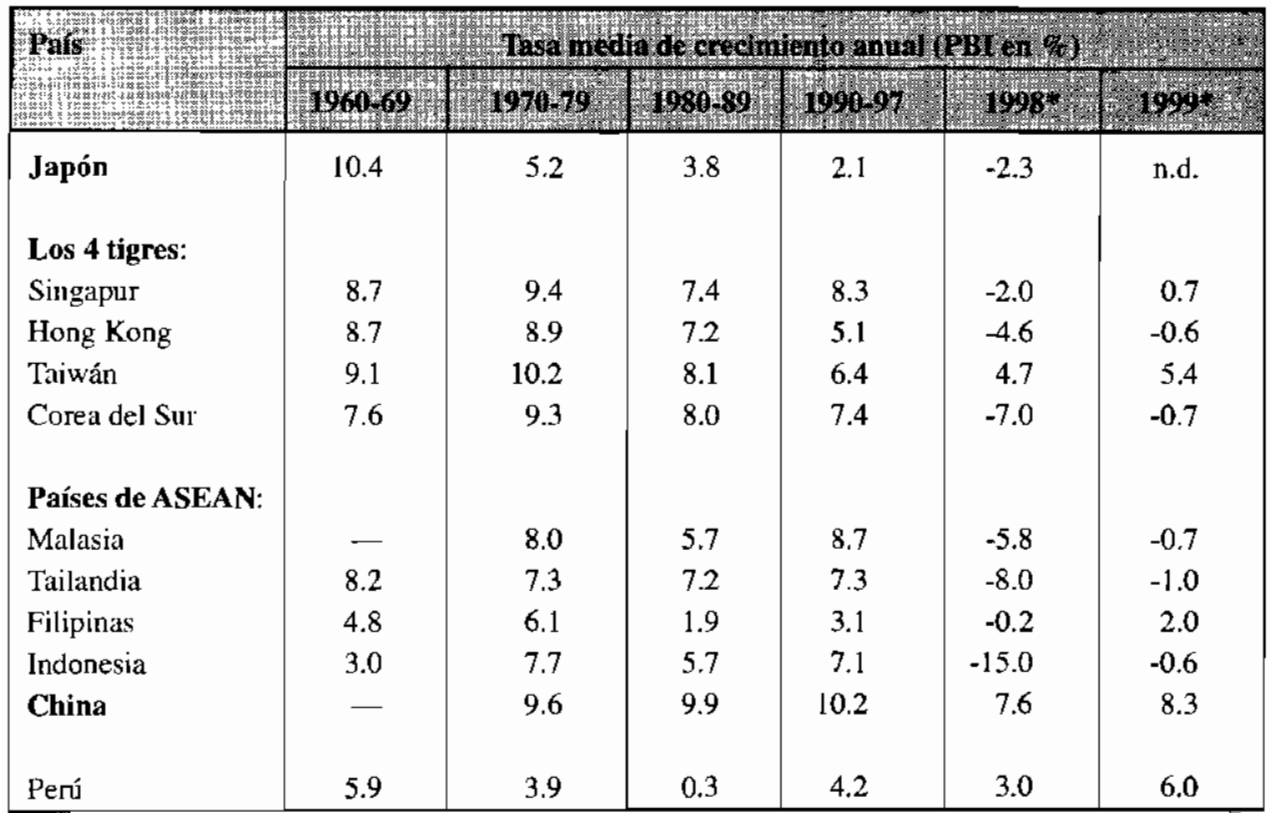

Fuente: «Ajia Keizai 1998» de Keizai Kikakucho, Tokio, junio de 1998.

* proyectado de la revista semanal «Far Eastern Economic Review» de Hong Kong del 15 de octubre de 1998.

para el Perí: Memoria 1997, BCR y otros. 
lo que el Perú exportó fueron los llamados productos tradicionales, esto es materias primas sin mayor procesamientover cuadro 22.Por ejemplo, de enero a julio de este año 1998 el Perú exportó sólo 3,035 millones de dólares, en eomparación con exportaciones por 4,009 millones de dolares en ese mismo periodo de 1997. Esto representa una caída de $2.5 .4 \%$ en nuestros ingresos por exportaciones (ver Nota Semanal No. $38 \mathrm{del}$ BCR del 9/10/98).

$\mathrm{El}$ menor ingreso por exportaciones en los primeros siete meses de este año 1998 , se debe a la menor venta de nuestros productos (menor volumen exportado, especialmente la harina de pescado que disminuyo el monto de sus exportaciones en un $80.1 \%$ entre enero y julio de este año, en comparación a enero a julio de 1997, esto fue a causa del fenómeno El Niño), pero también por el menor precio que estos mismos productos, mayormente las materias primas (excepto la harina de pescado), han experimentado desde que empezó la crisis hace mas de un año. Los precios de la mayoría de las materias primas que el Perú exporta han decrecido, y el precio del cobre por ejem- plo, cuyas exportaciones representaron en promedio casi un $20 \%$ del total de las exportaciones peruanas en los últimos 5 años, ha decaído en mas del $35 \%$ desde julio de 1997 a la fecha (comienzos de octubre de 1998). (ver cuadro 23).

Todas Ias materias primas que el Perú exporta, excepto la plata ( $y$ la harina de pescado), han decrecido de precio en el último año. El precio de la harina de pescado ha subido, pero esto se debe a que el recurso primario, los peces, prácticamente desaparecieron del mar peruano por el fenómeno El Niño. Pero al empczar a exportarse otra vez harina de pescado ahora que se acabo el fenómeno El Niño se prevé que el precio de este producto también podría bajar por la menor demanda en los países asiáticos donde China, Hong Kong y Japón son los principales compradores de este producto (ver por ejemplo opinión de Juan Raffo, Presidente de la Sociedad de Comercio Exterior -Comexperú- en el diario Cambio del 12/09/98). De hecho el precio de la harina de pescado, que subió a 725 US\$ por T.M. en febrero de 1998 , ha bajado a 680 US\$ por T.M. al 6 de octubre de 1998. Las ventas al exterior, especialmente a

\section{CUADRO 22}

\section{EXPORTACIONES POR GRUPO DE PRODUCTOS}

(en millones de dólares y en \%)

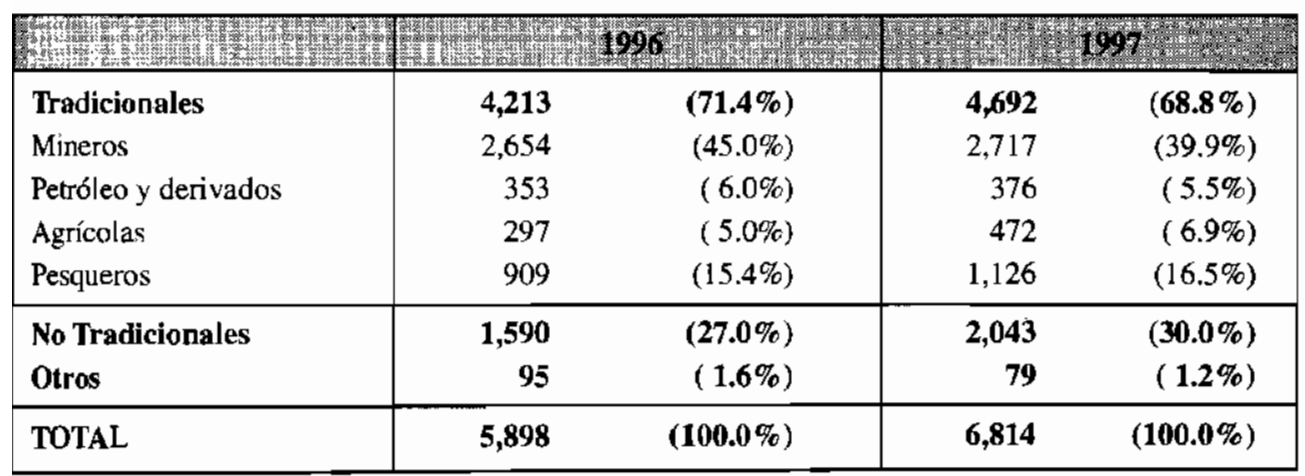

Fuente: Banco Central de Reserva, Nota Semanal No. 38, 9 de octubre de 1998. (pag. 82) 
CUADRO 23

EVOLUCIÓN DEL PRECIO DE ALGUNAS MATERIAS PRIMAS

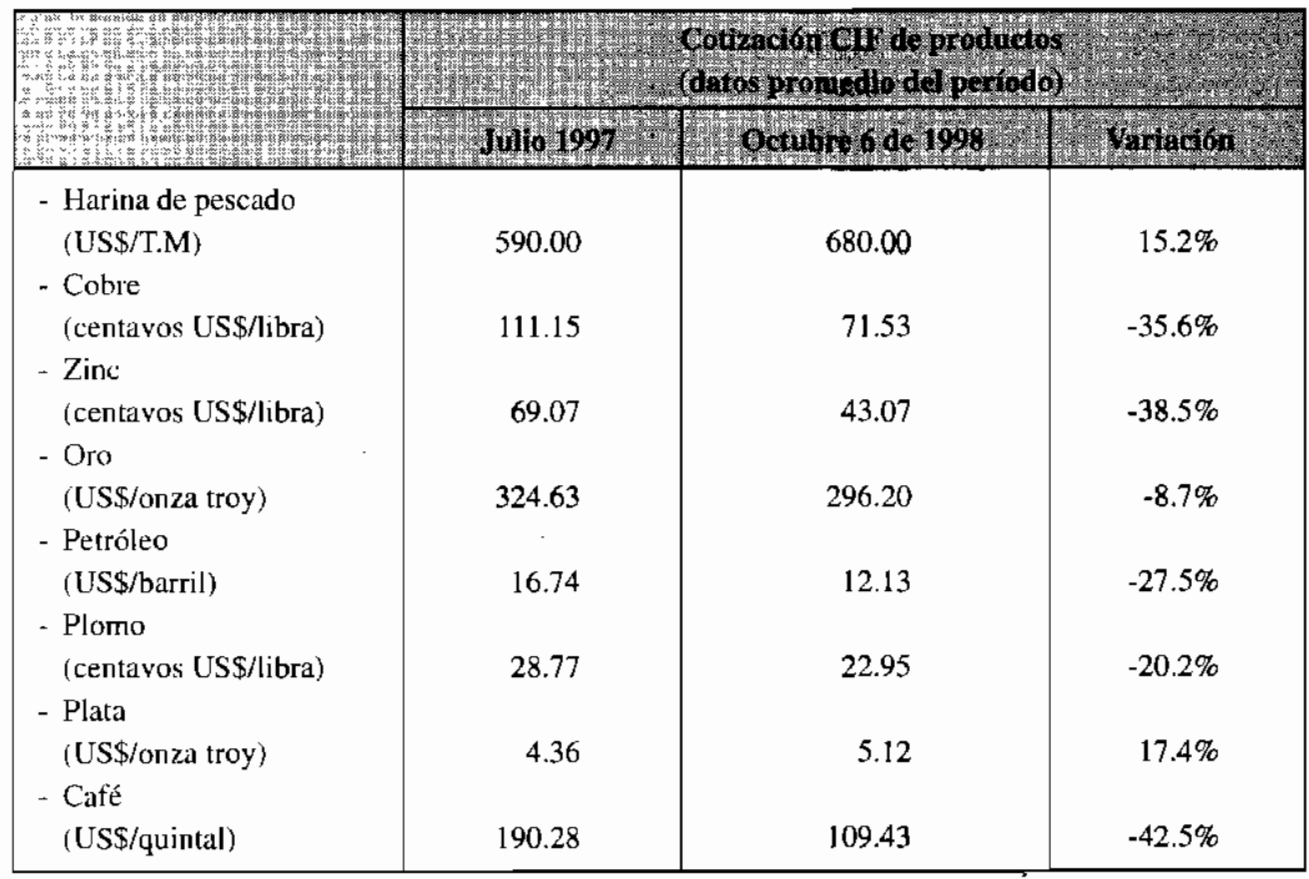

Fuente: Banco Central de Reserva, Nota Semanal No. 38, 9 de octubre de 1998. (pag. 51)

los países de Asia, han decaído en lo que va de este año, pero por otro lado nuestras compras desde Asia han aumentado en una gran proporción. El Perú exportó en 1997 el $21.67 \%$ del total de sus exportaciones a 9 países de Asia: Tailandia, Malasia, Indonesia, Filipinas, Corea del Sur, Japón, Hong Kong, China y Taiwán. Las importaciones ese mismo año desde esos 9 países fueron el $13.83 \%$ del total de nuestras compras del exterior. Ese año 1997 tuvimos un superávit comercial con los 9 países de 360.5 millones de dólares (con exportaciones por 1,428.4 millones de dólares e importaciones por 1,057.9 millones de dólares). Pero en la primera mitad de este año (enero a junio de 1998) las exportaciones a esos 9 países han decrecido de tal forma ( $y$ las importaciones han aumentado grandemen- te por la devaluaẹjón de las monedas de esos países) que ahora tenemos un déficit comercial de $\mathbf{3 4 2 . 9}$ millones de dólares con la región asiática. Las exportaciones en ese período fueron de solo 300.2 millones de dólares mientras que las importaciones llegaron a $643.1 \mathrm{mi}-$ llones de dólaress. Esto sumó un déficit comercial con la región asiática en la primera mitad de este año casi igual al monto del superávit comercial que el Perú tuvo en todo el año 1997 con esa región. De esta forma el déficit comercial con Asia ha contribuido a aumentar nuestro deficit comercial global. Esto es en si preocupante pues el Perú tradicionalmente ha tenido un superávit comercial con la región asiática. (todas las cifras anteriores son de Aduanas del Perú).

En general se espera que los precios de 
las materias primas que el Perú exporta no se recuperen el próximo año e incluso en más tiempo (por ejemplo, ver opinión de experto chileno en el diario Gestión 11/09/98 y de Gonzalo Raffo citada anteriormente). Si la economía mundial se deteriora mas, ineluso se prevé podría bajar aun más los precios de las materias primas.

Las menores exportaciones han ocasio- nado un incremento en el déficit comercial del Perí y en nuestro déficit en cuenta corriente. Se prevé que el déficit comercial este año 1998 sea de 2,800 millones de dólares (según eifras del gobiemo, ver euadro 24), aunque otros analistas creen que pueda ser mayor (por ejemplo Comexpenú predice un déficit comercial de 3,151 millones de dólares en 1998, con exportaciones de solo 5,736 millo-

\section{CUADRO 24}

\section{INDICADORES MACROECONÓMICOS}

(millones de US\$)

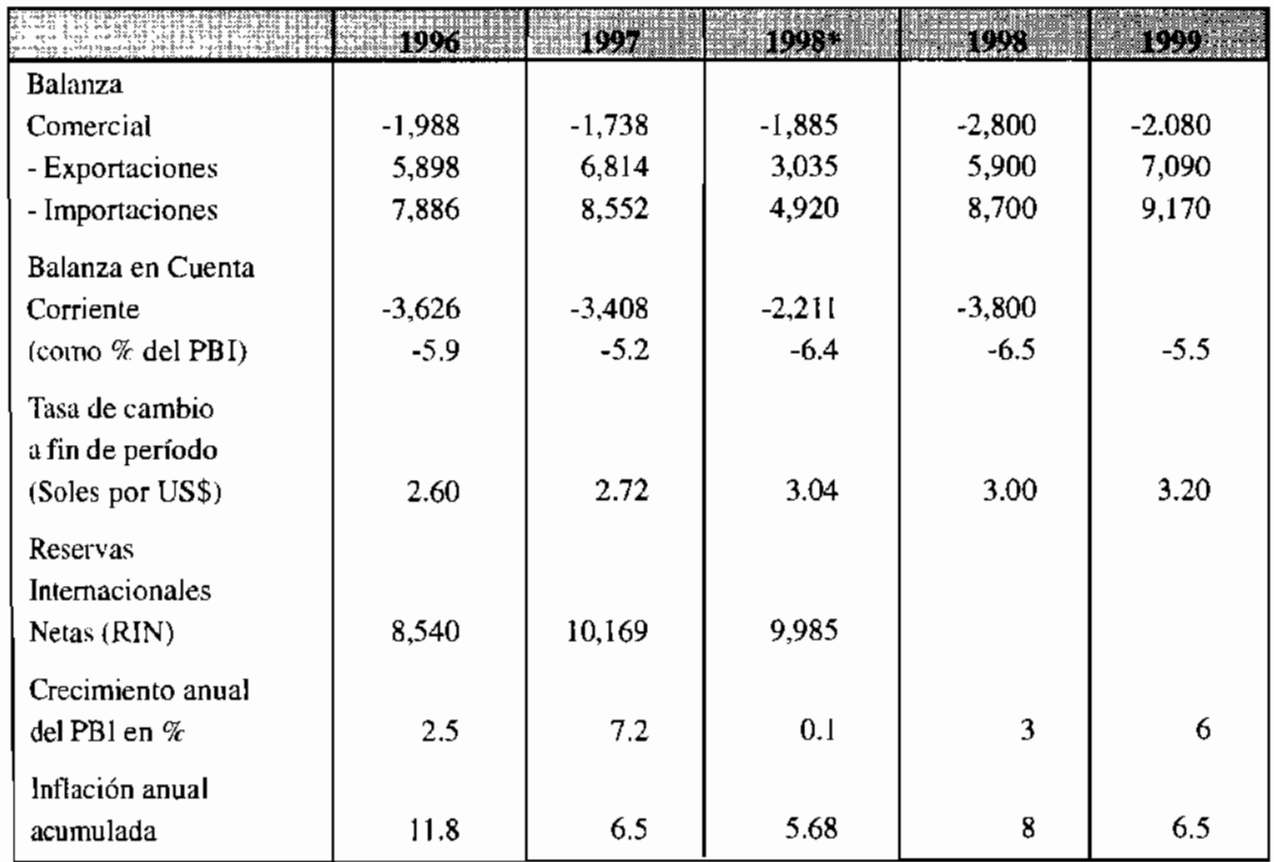

Fuente: Banco Central de Reserva, Nota Semanal No. 38, 9 de octubre de 1998.

* Balanza comercial: enero a julio

Balanza en cuenta corricnte: enero a junio

Tasa de cambio al $7 / 10 / 98$

Cifras del RIN al 7/10/98.

Crecimiento anual del PBI: enero a julio

Inflación anual acumulada a setiembre las cifras de 1998 y 1999 son proyecciones del gobierno, dadas en la exposición del Ministro de Economía Jorge Baca Campodónico en la sustentación del Presupuesto de la República 1999 en el Congreso de la República, el 11/09/98, y ratificadas después por otras autoridades del gobiemo. 
nes de dólares e importaciones de 8,887 millones de dólares - ver diario Cambio del 12/09/98).

Las proyecciones de comportamiento de las variables macroeconómicas para 1998 y 1999 del cuadro 24 son del gobiemo, y estas cifras, para algunos observadores, son en sí bastante optimistas. Se dice, por ejemplo, que la proyccción de una tasa de cambio de un valor de 3.20 soles por dólar para el fin del año 1999 no es real, tomando en cuenta que el sol ya llegó a alcanzar en un momento una cotización cercana a 3.10 soles por dólar a fines de agosto de este año 1998. Principalmente habrá una tendencia a la depreciación del tipo de cambio pues «el deterioro de los mercados financieros, traducido en una mayor tasa de interés para las líneas de crédito y en menor ingreso de capitales para el país empujara al alza el tipo de cambio» (según Elmer Cuba, analista de Macroconsult, en declaraciones al diario El Comercio, 1/09/98). Además varios países de Latinoamérica ya han devaluado su moneda y seria difícil que el Perú pueda resistir si la crisis se agudiza en la mayoría de los países de esta región.

El crecimiento de 6\% del PBI para 1999 también parece ser muy optimista para algunos observadores. Para Jorge Chávez, Presidente de Maximixe, «será realmente difícil que la economía crezca un $6 \%$ en 1999 , lo más probable es que el PBI crezca sólo 4.5\%, pues las exportaciones peruanas se verán afectadas por la continua caída de las cotizaciones internacionales de las materias primas, así como por la reducida afluencia de capitales externos y el incremento de las tasas de interés» (en declaraciones al diario El Comercio, 1/09/98).

2.- La turbulencia en los mercados financieros ocasiona la baja en las Bolsa de Valores en el mundo y en el Perú. La Bolsa de Valores de Lima descendió de principios de enero al 6 de octubre de este año 1998 un $30.4 \%$ en su Indice General y un $30.8 \%$ en su Indice Selectivo. La mayor parte de esta baja fue en el mes de agosto cuando el Indice General bajo un $26.2 \%$ y el Indice Selectivo un $28.9 \%$. (datos de la Nota Semanal del BCR No. 33 y 38 del 4/09/98 y 9/10/98 respectivamente).

Si bien tenemos una Bolsa dc Valores pequeña, que negocia en promedio menos de 15 millones de dólares diarios en estos momentos (ahora no llega ni a 10 millones de dólares, una fracción de lo que negocian otras Bolsas de Valores en Latinoamérica), y cuyo impacto en la economía del país no es muy grande de por sí, el verdadero impacto en la economía puede verse por el hecho de que una caída pronunciada en la Bolsa de Valores indica una salida de capitales al exterior y/o una reticencia de estos capitales a venir a mercados cmergentes como el Perú, y esto esta ocasionando un menor financiamiento a nuestro país y encareciendo el crédito. El Perú necesita créditos para financiar las inversiones de sus empresas y también para financiar los grandes proyectos mineros que empresas extranjeras planean poner en marcha.

La retracción del crédito a los llamados mercados emergentes de Latinoamérica, después de la crisis en los otros mercados emergentes de Asia y Rusia, pone en riesgo el financiamiento de los grandes proyectos mineros que se espera poner en marcha. Con la puesta en marcha de estos grandes proyectos mineros se espera aumentar la producción, exportar mas, y así disminuir el creciente déficit en cuenta corriente del país. Asimismo, de retrasarse estas inversiones, habría problemas en el financiamiento del déficit en cuenta corriente.

Por ejemplo, el gobierno espera tener de aquí al año 2002 grandes inversiones en proyectos mineros y petroleros. Se habla de una cifra de inversiones por 14,000 millones de dólares y esto, que en promedio son 2,800 millones de dólares al año, se espera puedan ayudar a financiar el déficit en cuenta 
corriente (ver cuadro 25. Varios de estos proyectos ya están en marcha).

3.- El tercer mecanismo de transmisión de la crisis asiática, ha sido a través de la presión a la devaluación que han experimentado las monedas de diferentes países. La mayoría de los países asiáticos han devaluado su moneda, Rusia lo hizo en forma traumática a partir del 17 de agosto, y ya varios países latinoamericanos como Chile, México, Colombia, to han hecho (Venezuela y Brasil también lo hicieron aunque en forma leve y Ecuador lo acaba de hacer en el último mes). El Perú tiene un sistema de tasa de cambio flexible, y la paridad cambiaria de la moneda se define en el mercado, sin intervención del gobiemo (como las autoridades gubernamentales se encargan de decir). Pero el Perú ya ha experimentado una devaluación de su moneda este año 1998 de mayor mag- nitud que en años anteriores. La paridad cambiaria era el 1 de enero de 1998 de 2.72 soles por dólar, el 7 de octubre de 1998 la paridad fue de 3.04 por dolar. El año 1997 la moneda se devaluó un $4.6 \%$ (paso de 2.60 soles por dólar a comienzos de año a 2.72 soles por dólar a fines de año). En lo que va del año 1998 el sol ya se devaluó un $12.0 \%$ (de 2.72 soles por dólar a comienzos de año a 3.04 soles al 7 de octubre de este año).

El gobiemo espera finalizar este año con una paridad cambiaria de 3.00 soles por dólar. Para el próximo año 1999 se espera tener a fin de año una paridad de 3.20 soles por dólar (una devaluación total de $6.6 \%$ ese año, ver cuadro 24)

La devaluación esta ocurriendo porque hay una menor oferta de dólares en el mercado (por la reticeneia de los capitales extranjeros a venir a mercados emergentes como el

\section{CUADRO 25}

\section{PRINCIPALES PROYECTOS MINEROS Y PETROLEROS QUE SUSTENTAN LA PROYECCIÓN DE MAYORES EXPORTACIONES EN EL MEDIANO PLAZO}

\begin{tabular}{|c|c|c|}
\hline Provecon & 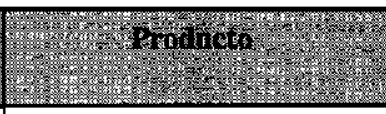 & 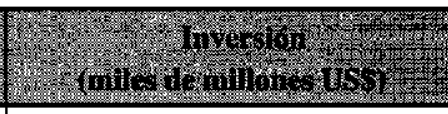 \\
\hline Southem & Cobre & 1.5 \\
\hline Proyectos de petróleo & Petróleo & 1.9 \\
\hline Antamina & Zinc/Cobre & 2.5 \\
\hline Yanacocha & Oro & 0.2 \\
\hline Michiquillay & Cobre & 0.5 \\
\hline Cerro Verde & Cobre & 0.3 \\
\hline Pjerina & Oro & 0.4 \\
\hline Cajamarquilla & Zinc/Cobre & 0.3 \\
\hline Tintaya & Cobre & 0.2 \\
\hline Opaban & Hierro & 0.2 \\
\hline Toromocho & Zinc/Cobre & 0.2 \\
\hline Otros proyectos mineros & & 1.8 \\
\hline Total & & 10.0 \\
\hline
\end{tabular}

Fuente: Exposición del Ministro de Economía Jorge Baca Campodónico ante inversionistas extranjeros: «The Peruvian Economy: Challenge and Outlook», julio 1998.

Nota: la cifra de 14,000 millones se alcanza con otros proyectos mineros como la Granja, Quellaveco, Gas de Camisea. 
Perú, por las menores exportaciones), o porque algunos de estos capitales se están retirando de los mercados emergentes como el Perú. Además, la presión devaluatoria existe, pues los agentes económicos creen que la situación económica puede empeorar ( $y$ la moneda nacional devaluarse) y prefieren tener sus activos en una moneda fuerte como el dólar.

El problema de una gran devaluación de la moneda ел el Perú es que la mayor parte de la liquidez en el sistema bалcario nacional está en dólares. Al 22 de setiembre de 1998, del total de liquidez del sistema bancario nacional que ascendió a 39,387 millones de soles. el $69.5 \%$ es en moneda extranjera (dólares) y solo el $30.5 \%$ en soles (Banco Central de Reserva, Nota Semanal No. 38, 9/10/ 98). EI Perú tiene una economía dolarizada donde la mayoría de los prestamos a las empresas y familias se hacen en dólares. De ocurrir una devaluación grande de la moneda nacional, todos se verían obligados a pagar mas soles por esos prestamos y ahí si habría un problema grande (aparte de que el gobierno necesitará mas soles para comprar los dólares con que pagar el servicio de la deuda extcrna que este año 1998 llega a casi 1,700 millones de dólares).

Las empresas y familias se prestan en dólares y no en soles por dos razones: Primero la liquidez en soles es escasa. De enero al 22 de setiembre de este año la liquidez en moneda nacional en el sistema bancario nacional decreció en $7.4 \%$, mientras la liquidez en moneda extranjera aumento en $13.6 \%$. La segunda razón, que tiene que ver con la primera, es que la tasa de interés activa en soles es altísima comparada eon la tasa de interés activa en dólares. A la primera semana de octubre de este año la tasa activa promedio anual en soles hasta 360 días es $33.80 \%$ y la tasa en dólares era de $15.55 \%$. (a mas de 360 días la tasa activa promedio anual en soles es de $53.72 \%$ y en dólares solo $16.31 \%$ )

\section{B.- Medidas para afrontar Ia crisis asiática}

Para el gobiemo dcl Perú, la economía peruana está en buena posición, casi mejor que ningún otro país latinoamericano, para enfrentar los efectos negativos de la crisis asiática. Para esto el gobierno señala los siguientes tres puntos: Un déficit fiscal cero, una tasa de cambio flexible, y un gran nivel de Reservas Internacionales Netas. Además el sistema fínanciero peruano al parecer no tiene problemas como los que originaron la crisis eu los paises asiáticos. Veamos un poco esto.

a. El país mantiene un déficit cero del seetor público, e incluso se proyecta un superávit fiscal el año 1999 y los años ģiguientes. Al no tener un deficit en las cuentas del gobiemo no hay necesidad de que el gobiemo tenga que financiapr su déficit (corriendo el peligro de tener mayor emisión monetaria y así genefar inflación, como era común hasta antes de 1990), ni necesita prestarse del extranjero para esto. Entonces el gobierno no necesita financiamiento, que en estos momentos de crisis es siempre escasọ y caro. Además, en estos tiempos de turbulencia financiera, el tener un défiçit fiscal es visto ahora como un símbolo de debilidad de la economía y susceptible de fuga de capitales al exterior (ver el caso actual de Brasil que tiene un grạn déficit fiscal, de mas de 7\% de su PBI).

b. El país sigue un sistema de tasa de cambio flexible, en el que el valor de la moneda frente a la divisa extranjera lo deçide el mercado. Según los analistas eeonómicos, este sistema es en gran medida convieniente en épocas de turbulencia financiera y presión a la devaluación. Si tuviéramos un sistema de tasa de cambio fijo, en el que el gobierno fija el precio de la moneda y se compromete a defender esta ante los ataques especulativos para devaluarla, el gobierno perdería divisas (reservas) tratando de defender el valor fijo de su moneda. Esto le ha pasado a Brasil donde se calcula que el Ban- 
co Central de ese país ha perdido cerca de 30,000 millones de dólares (de un total de 70,000 millones de dolares de sus reservas internacionales) en los últimos tres meses tratando de defender el valor de su moneda, o le paso también a los países asiáticos como Tailandia e Indonesia que en la primera mitad de 1997 se quedaron sin reservas defendiendo la paridad fija de su moneda y tuvieron que acudir por ayuda al Fondo Monetario Internacional.

c. El gobierno tiene un amplio colchón de Reservas Internacionales Netas (RIN) para defender la economía en momentos de inestabilidad financiera. Al 7 de octubre de 1998 el Perú contaba con 9,985 millones de dólares de RIN. Además, según la exposición del Ministro de Economía Jorge Baca Campodónico en la sustentación del Presupuesto de la República 1999 en el Congreso de la República el 11/09/98, el Perú es el único país de la región latinoamericana que ha ganado reservas desde que la crisis asiática empezó a extenderse al mundo (setiembre de 1997). De setiembre de 1997 a julio de 1998 el Perú ganó 732 millones de RIN, mientras que Chile por ejemplo, otra economía vista como sólida en la región, perdió en ese lapso 2,450 millones de dólares. También se mencionó que las reservas Internacionales Netas cubren más de 6 veces la masa monetaria del país y más de 14 meses de importaciones.

d. Hay que señalar que el sistema financiero peruano no tiene mayores problemas de solvencia o liquidez y que la Superintendencia de Banca y Seguros tiene estrictas normas de control del sistema financiero nacional. El Ministro de Economía señaló en su exposición ante el Congreso que el sistema financiero es liquido y cuenta con fondos disponibles que representan el $80 \%$ del total de sus obligaciones inmediatas; además los bancos peruanos están debidamente aprovi- sionados y sus ratios de capitalización sobre activos son más exigentes que los recomendados por el Aeuerdo de Basilea. Las apreciaciones anteriores son respaldas por diversos analistas, especialmente por los analistas de los Bancos de Inversión como Pablo Secada del Santander Investment, y Alfredo Thorne del J.P. Morgan (ver entrevistas en diarios, por ejemplo el diario El Comercio del 30/08/ 98 y 13/09/98).

En todo caso, aunque el Perú esté en una mejor posición que varios países latinoamericanos por ejemplo, la crisis asiática ya esta afectando la economía y varios sectores del país (como el sector industrial) reclama que el gobiemo haga algo para disminuir los efectos de la crisis económica. Por ejemplo se menciona 3 áreas que están siendo las mas afectadas y que requerirán acción del gobierno:

1. La drástica devaluación de las monedas en Asia ha incrementado las importaciones desde esa región. Esto esta perjudicando a sectores como los textiles, confecciones, plásticos, etc. Especialmente el sector de textiles y confecciones es el más afectado. Se demanda medidas para eontener este incremento de las importaciones de Asia que se dice esta dañando la industria nacional.

2. Hay una presión devaluatoria y el sol ya se ha devaluado en lo que va del año en un $12 \%$. Si hay una devaluación muy grande esto puede afectar la economía en general. Algunos analistas demandan de que no se permita una devaluación brusca de la moneda (ver por ejemplo declaraciones del economista Julio Velarde del 4/09/98 en el diario El Comercio).

3. La contracción en la llegada de capitales del exterior, producto de que los capitales extranjeros no quieren venir a los mercados emergentes como el Perú, esta creando una falta de li- 
quidez en el sistema financiero y además encarece las líneas de crédito del exterior. Se pide dar más liquidez al sistema financiero.

\section{¿Frente a los problemas mencionados en las tres áreas, qué se está haciendo en el Perú?}

1. Medidas para combatir el súbito incremento de las importaciones asiáticas.

El sector industrial textil está pidiendo al gobierno que tome medidas para defender a esle sector que enfrenta serios problemas desde hace mas de un año, no solo por el súbito incremento de las importaciones de Asia, sino también por el efecto del fenómeno El Niño.

Según declaraciones de David Lemor, Presidente dcl Comité de Confecciones de la Sociedad Nacional de Industrias, en los últimos dos años la industria de textiles, confecciones y afines ha sufrido una pérdida aproximada de 700 millones de dólares anuales como consecuencia del fenómeno El Niño y la crisis asiática. Por eso se requiere medidas que impidan un mayor deterioro de la industria, tal y como se viene realizando en orros parses. "La crisis asiática ha afeclado a muchas naciones que se han visto obligadas a adoptar algunos mecanismos que les han permitido hacer frente a estos probiemas. El Perú es el único país que no hace nadia para proteger su industria y los resultados están a la vista» (declaraciones en el diario El Comercio del 15/09/98).

$\mathrm{E}$ sector industrial pide varias medidas para derener este súbito incremento de las imporlaciones, especialmente la aplicación de cláusulas de salvaguarda, pero también otras medidas como valores mínimos de aforo, valores por peso, etc.

J.a aplicación de cláusulas de salvaguarda contra las impontaciones de Asia es un tema que se está debatiendo en estos momentos. No solo los industriales piden esta medida, también Prompex (Comisión de Promoción de las Exportaciones), apoya la dación de esta medida y según manifiesta el Presidente de Prompex, Ricardo Márquez, que es también el Primer Vicepresidente de la República, hay disposición del gobierno para estudiar este tema con seriedad y prontitud. Sin embargo, en el gobierno hay una eorriente contraria a la aplicación de medidas de salvaguarda. El Ministro de Economía Jorge Baca se opone a esta medida pues la considera proteccionista, que va a generar represalias contra las exporiaciones del Perú, y que fomentara la ineficiencia en el sector industrial. Esto en realidad no es así pues las cláusulas de salvaguarda cstán reconocido como una de las medidas legítimas temporales que pueden tomar los países miembros de la Organización Mundial del Comercio y como tal no generaría represalias.

La industria textil y de confecciones está en crisis porque además está amenazada por la llegada de ropa usada importada (aunque el Congreso de la República aprobó una ley a fines de setiembre para impedir esto). En todo caso hay serios problemas económicos en el sector de textiles y de confecciones, que es el sector más grande en términos del volumen de empleo que genera, y además es la industria de mayor valor agregado con que cuenta nuestro país.

En todo caso, la medida de aplicación de cláusulas de salvaguarda pedida por los industriales, es solo una medida temporal como los mismos industriales proclaman, y lo que se requiere para poder competir en igualdad de condiciones con los productos extranjeros, es la eliminación de los llamados «sobrecostos» (eliminación del FONAVI, Impuesto Extraordinario a los Activos Netos, etc.).

2. Erente a la presión devaluatoria contra el sol, cl Banco Central de Reserva a través de su Presidente Germán Suárez, ha reiterado que ante una especulación contra el dólar o una brusca deyaluación de la moneda, el Banco Central de Reserva (BCR) intervendrá en el mercado (ver declaraciones de Germán 
Suárez en el diario Gestión del 13/10/98). Si bien es cierto que la política del gobiemo es dejar que la tasa de cambio se determine por el mercado, hay la decisión política de no dejar que la moneda se dispare en su devaluación pues esto traerá trastornos a la economía.

La devaluación de la moneda es un tema delicado pues si bien una devaluación grande es perjudicial para la economía, hay que tener en cuenta de que muchos países latinoamericanos ya han devaluado su moneda, $y$ si el Perú no devalúa su moneda en una proporción similar, el país estará perdiendo competitividad en sus exportaciones, ya no sólo frente a los países asiáticos, sino también frente a los propios países latinoamericanos (Según el presidente del BCR, el Penú ya ha ganado algo de competitividad, con una devaluación de mas de $12 \%$ este año, y una inflación interna de menos de $6 \%$ hasta ahora. ver entrevista anterior en el diario Gestión). Ademâs defender a como de lugar la tasa de cambio ante presiones reales a una devaluación hará que el país pierda reservas intemacionales, como ha pasado ya con Brasil. por ejemplo.

Para aumentar la liquidez en el sistema bancario y también para aliviar la presión devaluatoria contra el sol el BCR decidió el 7 de setiembre de 1998 bajar la tasa de eucaje promedio a los depósitos en moneda extranjera de $43.8 \%$ a $42.3 \%$. Esta baja del $1.5 \%$ en el encaje en dólares rige a partir del 1 de octubre del presente año y se calcula liberara recursos por 137 millones de dólares. Esto podría bajar la tasa de interés en dólares y en todo caso liberara recursos para ser prestados a las empresas.

Hay que recordar que el gobierno ya hace más de tres meses había disminuido de $45 \%$ a $35 \%$ la tasa de encaje marginal a los depósitos de moneda extranjera. Si la crisis económica a nivel mundial continúa y si el flujo de capital extranjero disminuye hacia el Perú, medidas como ésta y la anterior serán necesarias para aliviar la falta de liquidez en el sistema bancario.

En la reunión anual del Banco Mundial (BM) y del Fondo Monetario Internacional (FMl) de comienzos de octubre, asistieron el Presidente de la República y el Ministro de Economía entre otras altas autoridades del gobiemo peruano. En esta reunión el Perú ha asegurado algunas líneas de crédito del exterior, como del Banco Interamericano de Desarrollo (BID), del Banco Mundial y aun firmo un acuerdo con el FMI para tener alguna línea de crédito que pudiera ser usada en caso de emergencia. Se espera que con estas nuevas líneas de crédito, la escascz de liquidez que actualmente atraviesan las ernpresas y el sistema bancario en el país puedan ser aliviadas.

\section{La crisis asiática: ¿Hasta cuándo?}

La crisis asiática, que ahora ha dejado de ser una crisis regional para convertirse en una crisis a nivel mundial, al parecer se prolongará por lo menos el próximo año. Los efectos en varios países de la región latinoamericana han sido grandes y algunos calculan que el crecimiento por ejemplo en Latinoamérica podría ser $1 \%$, o menos en 1999.

El pronóstico anterior, de especialistas en Latinoamérica de Wall Street, es quizás demasiado pesimista, pero la explicación que dan para este bajo crecimiento es bastante razonable y es principalmente porque los precios de las materias primas no se recuperaran e incluso podrían bajar mas el próximo año, no solo por la crisis asiática que es coyuntural, sino porque hay una clara baja en la demanda a nivel mundial por estos productos, algo que se mantendrá por mucho tiempo. Latinoamérica es una región que depende mucho de las exportaciones de materias primas y por eso su crecimiento económico será menor. Uno de los países bastante dependiente en materias primas es el Perú (ver reporte de la reunión en el dia- 
rio Gestión del 14/09/98).

Otros hablan incluso de una crisis económica a nivel mundial similar a la Gran Depresión de 1929 en adelante. Aunque este panorama también es demasiado pesimista, lo real es que para el Perú el factor más importante es como evoluciona Latinoamérica y especialmente Brasil. Los capitales extranjeros ven al Perú como parte de la región emergente de Latinoamérica, y si Latinoamérica tiene problemas, el Perú también tendrá problemas. Y si Brasil tiene problemas, Latinoamerica tendrá problemas. $Y$ Brasil en estos momentos está en la mira de todos por su gran déficit fiscal y su moneda para muchos sobrevaluada. Hay una presión fuerte hacia la devaluación del real, la moneda brasileña, y el gobiemo brasileño defiende su moneda vendiendo dólares y disminuyendo así peligrosamente el nivel de sus reservas internacionales. La reelección del Presidente Cardoso en Brasil se espera pueda ver a Brasil tomar algunas medidas impopulares quizás pero que alejen el fantasma de una crisis mayor en Latinoamérica.

Como la reunión de especialistas de Wall Street notó, la crisis económica actual muestra las debilidades de la región latinoamericana en la que mnchos países son dependientes de las exportaciones de materias primas. El Perú lo es especialmente pues casi el $70 \%$ de lo que exportamos son materias primas. El Perú depende de las materias primas no solo porque constituyen la mayor parte de nuestras exportaciones, y si los precios de estas materias primas se mantienen bajos, 0 bajan aun más, exportaremos menos y nuestro déficil en cuenta corriente de por sí bastante alto, podría aumentar. También dependemos de las materias primas pues son la principal atracción de nuestro país para los inversionistas extranjeros. Si los precios de las materias primas se mantienen bajos, y el financiamiento es escaso por la reticencia del capital extranjero a venir a países como el Perú, las inversiones hacia la explotación de estos recursos no vendrán. El gobierno pro- yecta que de aquí en adelante el $80 \%$ o más del financiamiento del déficit en cuenta corriente sea cubierto por inversiones, principalmente inversiones en proyectos mineros. Pero si los precios de estos productos siguen bajos, y el financiamiento escasea, la inversión en estos proyectos disminuirá y con esto el financiamiento del dêficit en cuenta corriente se hará más diff́cil.

\section{Conclusión: 1999 será nn año difícil para la economía peruana}

Para muchos analistas, se hace cada vez más difícil que el gobierno alcance la meta de un crecimiento anual del PBI de 3\% este año. Lo más probable es que se ubique en el rango de $2 \%$ a $2.5 \%$ anual. El crecimiento de 6\% para el año 1999 también no parece real, y muchos analistas creen que una cifra mas adecuada seria de $4.5 \%$ (aunque sí el crecimiento es de solo $2 \%$ annal este año 1998 , el próximo año se podría creçer un $6 \%$ anual pues se estaría partiendo de una base muy baja).

El próximo año será un año difícil para la economía del Perú por la secuela de la crisis asiática. Si esta se prolonga (ya no por la crisis de los mismos países asiáticos, sino por su impacto en la economía de países como de Latinoamérica e incluso de los EE.UU.) eso significa bajos precios de las materias primas y menores ingresos por exportaciones. Esto hará que el déficit en cuenta corriente se mantenga encima del $6 \%$ del PBI, un nivel peligroso sẹgún los estándares internacionales. Para financiar este déficit se espera inversiones que podrían disminuir por las condiciones del mercado internacional. A lo anterior hay que agregar que 1999 es un año electoral con miras a las elecciones del año 2,000. Todo parece indicar que el Presidente Fujimori postulara a la reelección y entonces habrá la tentación de gastar (como se hizo en 1994 previo a las elecciones generales de 1995). Pero si el gobierno aumenta el gasto fiscal, habrá un déficit fiscal y esto debilitara a la economía y lo hará suscepti- 
ble de una retracción del capital extranjero agudizándose mas la crisis.

Si bien el gobierno desde 1990 ha estabilizado la economía del Perú, ha eliminado el déficit fiscal y las inversiones han aumentado grandemente, la crisis asiática muestra otra vez la vulnerabilidad de la economfa peruana que depende de las exportaciones de materias primas cuyos precios están ahora en baja. Para hacer menos vulnerable la economía peruana a los vaivenes de la economía mundial se debería fomentar exportaciones de productos de mayor valor agregado, de la industria y la agricultura, y de esta forma crear también mas empleo, pues estos seetores crean más puestos de trabajo que la simple extracción de recursos primarios, y al fin y la cabo la falta de empleo, es quizás el problema más agudo de la eeonomía peruana en la actualidad.

\section{TERCERA PARTE}

\section{EL PERÚ Y EL APEC}

El Perú ha sido admitido en noviembre de 1998 al APEC. Esto es el Foro de Cooperación Económica Asia - Pacífico. Pero el APEC es sólo una de las instituciones que actúan en la Cuenca del Pacifico (llamada también región Asia - Pacífico) de la que el Perú es miembro. Primero presentaremos aquí algunas institueiones de la región Asia - Pacífico, luego hablaremos algo sobre el APEC y la importancia para el Perí, y luego daremos algunos datos sobre los miembros del APEC, futuros socios del Perú.

\section{ORGANIZACIONES EN LA REGIÓN ASIA - PACÍFICO}

\section{APEC (Asia - Pacific Economic Cooperation)}

Foro de Cooperación Económica Asia - Pacífico

La organización más importante en la región Asia - Pacífico o también llamada la Cuenca del
Pacifico. Creado en 1989, agrupa a funcionarios de más alto nivel de las economías miembros. Se encarga de diseñar y ejecutar políticas para lograr un incremento en las relaciones económicas (comercio, inversión) y cooperación entre los países miembros. Para el año 2020 se planea crear un área de libre comercio e ínversiones entre sus miembros.

Agrupa a 18 economías. A partir de la reunión de Kuala Lumpur de noviembre de 1998 se ha incorporarado 3 nuevos miembros: Penú, Rusia y Vietnam. Actualcs miembros:

$\begin{array}{ll}\text { Del continente } & \text { Del continente } \\ \text { americano: } & \text { asiático: } \\ \text { EE.UU. } & \text { Japón } \\ \text { Canadá } & \text { Corea del Sur } \\ \text { México } & \text { Taiwán } \\ \text { Chile } & \text { Singapur } \\ & \text { Hong Kong } \\ & \text { Tailandia } \\ & \text { Malasia } \\ & \text { Indonesia } \\ & \text { Filipinas } \\ & \text { Brunei } \\ & \text { China } \\ & \text { Papua Nueva Guinea } \\ & \text { Australia } \\ & \text { Nueva Zelandia }\end{array}$

\section{PECC (Pacific Economic Cooperation Council)}

Consejo de Cooperación Económica del Pacifico

Creado en 1980, es un organismo tripartito que agrupa a funcionarios de gobierno, empresarios y académicos de cada economía miembro.

Agrupa a 22 economías. Perú es míembro del PECC desde 1991. Elabora estudios y diseña políticas para lograr una mayor relación en todos los campos entre los países miembros.

\section{PBEC (Pacific Basin Economic Council)}

Consejo Económico de la Cuenca del Pacifico

Creada en 1967, agrupa a los empresarios privados de la Cuenca del Pacifico.

Agrupa a 23 economías. Perú es miembro 


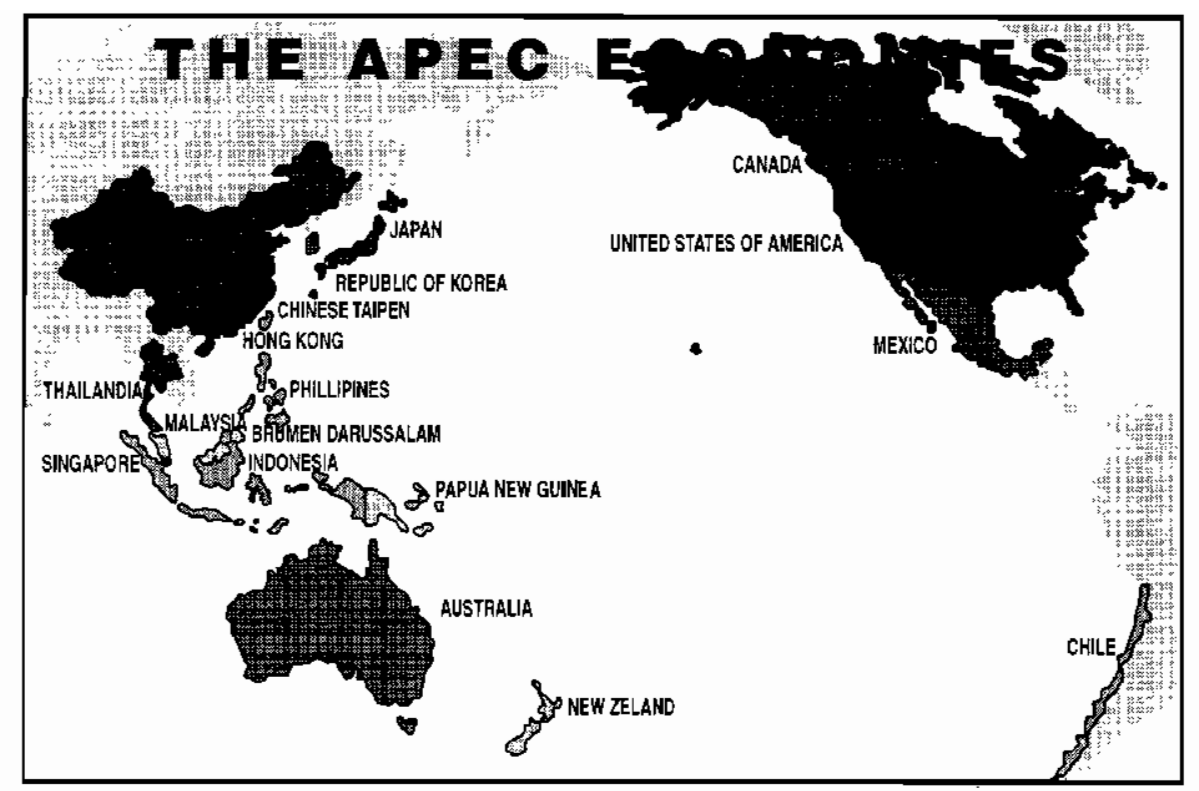

del PBEC. Trata de incrementar los negocios entre los países miembros a través del mayor conocimiento mutuo entrc los empresarios de los países miembros.

\section{¿Por qué es importante el APEC para el Perú?}

La admisión oficial del Perú al Foro de Cooperación Económica Asia - Pacífico (Asía Pacific Economic Cooperation - APEC) en la reunión de Malasia en noviembre de este año 1998, es importante por las siguientes razones:

Primero.- Hasta noviembre el APEC lo formaba 18 de las más dinámicas economías del mundo. En el continente americano tenemos: EE.UU.. Canadá, México y Chile. En el continente asiático, el resto, 14 economías: Japón; Corea del Sur, Taiwan, Hong Kong (ahora parte de China), Singapur: Malasia, Tailandia, Indonesia. Filipinas, Brunei; China, Papua Nueva Guinea, Nueva Zelandia y Australia.

A partir de este novienbre se han unido 3 miembros más: Perí, Rusia y Vietnam.
Segundo.- Los países del APEC buscan tener al año 2020 un área de libre comercio e inversiones, donde sus miembros puedan hacer negocios entre sí sin ninguna traba. Esto significará un gran mercado para los productos peruanos y fuente de capital para las inversiones en nuestro país.

Tercero.- El APEC reúne ạ las economías más grandes del mundo. En 1995 se calcula que sus 18 miembros tenían un PBI de 13 trillones de dólares, que representa aproximadamente $55 \%$ del ingreso mundial, y en 1996 participaban del $50.6 \%$ del comercio global (incrementó su participación en el comercio mundial desde un nivel de 43.4\% en 1986). Además, los 18 miembros actualęs del APEC reúnen a casi la mitad de la población mundial. Esto significa el mercado más grande para un país como el Perú.

Cuarto.: El APEC reúne a economías diversas respecto a su nivel de desarrollo económico. En el APEC están las economías más grandes, ricas e industrializadas del mundo, como 
EE.UU. y Japón, por un lado, y Filipinas y Chile, economías en crecimiento y desarrollo del otro. Obviamente esta diversidad en el nivel de desarrollo de las economías miembros del APEC significa que las oportunidades de hacer negocios son amplias en diversos campos, en diversos productos a exportar, en diferentes consumidores a satisfacer.

Quinto.- El APEC tiene importantes Grupos de Trabajo que trabajan para alcanzar una liberalización más rápida del comercio y las inversiones entre sus miembros, por ejemplo, están el Grupo de Trabajo de Turismo, el Grupo de Trabajo de Pesquería, campos en los que el Perú tiene ventajas que explotar. Pero también el APEC contempla un Sub Comité de Cooperación Económica y Técnica, el llamado Ecotech, el cual contcmpla acuerdos de cooperación en el desartollo de diversos campos, como por ejemplo, la promoción de la pequeña y mediana empresa, el desarrollo de recursos humanos, campos en el que un país como el Pcrí sc puedc beneficiar de las experiencias exitosas de otros miembros más desarrollados en esos campos.

\section{¿Qué es el APEC y cómo ha evolucionado} en el tiempo?

Este noviembre de 1998 se reunieron en Kuala Lumpur, Malasia, los países miembros del APEC (Asia Pacific Economic Cooperation, o Foro de Cooperación Económica Asia - Pacífico) en su 10 ma. reunión general y 6ta. de Jefes de Estado. En esta reunión han sido admitidos como nuevos miembros a este importante Foro el Perú, Vietnam y Rusia. Es un gran logro para el Perú el ingreso a este exclusivo Foro que agrupa a las economías más grandes y dinámicas del mundo pero también presenta un gran desafió de ser competitivos para aprovechar esa oportunidad. La reunión ha sido sumamente importante pues la ma- yoría de los países asiáticos del APEC y Rusia están en serios problemas económicos que amenazan la estabilidad económica del mundo. El cómo el APEC puede considerar este problema dará la pauta para el futuro avance del APEC en su meta de lograr un área de libre comercio e inversiones al año 2020 .

\section{¿Qué es APEC?}

El APEC reúne a las economías más grandes y dinámicas del mundo. En 1995 se calcula que sus 18 miembros tenían un Producto Bruto Interno (PBI) de 13 trillones de dólares, que representa aproximadamente $55 \%$ del ingreso mundial, y en 1996 del $50.6 \%$ del comercio global.

APEC fue creado en 1989 en respuesta a la creciente interdependencia entre las economías de la región Asia - Pacífico.

Sus objetivos son:

- Sostener el crecimiento y desarrollo de la región para el bien común de su gente y, de esta forma, contribuir al crecimiento y desarrollo de la economía mundial.

- Para reforzar las positivas ganancias de la región y dc la economía mundial, que resultan de la creciente interdependencia económica, y para estimular el flujo de bienes, servicios, capital y tecnología.

- Desarrollar y fortalecer el sistema multilateral abierto en el interés de la región Asia - Pacífico y de las otras economías; y,

- Redueir las barreras al comercio en bienes y servicios entre los participantes en una manera consistente con los principios de la Organización Mundial del Comercio, OMC, y sin detrimento de las otras economías.

El APEC reúne a füncionarios de gobierno del más alto nivel, a través de las reuniones de Ministros de Estado desde su creación en 1989, y que desde 1993 también congrega en cada reunión anual a los Jefes de Estado.

\section{¿Quiénes lo conforman?}

En el continente americano 5 eeonomías: EE.UU., Canadá, México, Chile, y Perú. 
En cl continente asiático, el resto, I6 economías: Japón, los cuatro tigres: Corea del Sur, Taiwan, Hong Kong (ahora parte de China), Singapur: los países de ASEAN: Malasia, Tailandia. Indonesia, Filipinas, Brunei; China, Papua Nueva Guinea, Nueva Zelandia, Australia, Vietnam y Rusia.

\section{Características.-}

- Diversidad de sus economías y acuerdo por consenso.

En el APEC están las economías más grandes del mundo como EE.UU. y Japóu, por un lado, y Filipinas y Chile, economías en crecimiento por stro lado. Las economías más ricas, como Japón con un Producto Nacional Bruto (PNB) per cápita en 1996 de 40,940 dólares, y China con solo 750 dólares per cápita ese año. Economías muy industrializadas como EE.UU. y Japón, o economfas con todavía un $60 \%$ de su población en el sector agrícola como Chiua.

Juslamente esta diversidad en los niveles de desarrollo económico hace qne los países tengan diferentes intereses que defender. Por ejemplo, APEC en 1994 decidió que para el año 2020 los paises establecerán entre ellos un área de libre comercio y un régimen de liberalización de las inversiones. Los países industrializados como EE.UU. querían que esto sea alcanzado en una fecha más eereana. Los países cn desarrollo pidieron más tiempo para defender y desarrollar su industria uacional. Al final se acordó por consenso que los países industrializados abran su mercado en el año 2010 y se den 10 años más para los países en vías de desarrollo, hasta el año 2020.

Los acuerdos por consenso se toman para impedir que los países más grandes y ricos puedau imponer sus intereses frente a países pequeños y en vías de desarrollo.

Además de lo anterior, cada país al comprometerse a abrir su mercado en un tiempo determinado, no tiene una obligatoriedad de alcanzar esa mela en esa fecha. La razón es que no hay un organismo supranacional en el APEC, como lo hay en la Unión Europea y la Comunidad Andina por cjemplo, que pueda obligar a un país a hacer cumplir sus compromisos. No hay en el APEC una Corte de Justicia o Tribunal Supranacional que castigue a un pafs por el no cumplimiento de un acuerdo. Esto significa que cada país tieue la discrecionalidad en el manejo de los acuerdos, lo que permite libertad a un país para manejar las fechas-límite de los acuerdos de liberalización conforme a sus intereses (aunque con el Plan de Acción de Manila de 1996 -ver más abajo-, se busca poner cronogramas a los programas de liberalización comercial por sectores).

\section{- Regionalismo abierto}

Significa que el proceso de cooperación regional actualmente en marcha tiene como fin no solo la reducción de barreras internas (intrarregionales) entre los miembros del APEC, simo también la reducción de las barreras externas al comercio con aquellas economías que no son parte de la región, expresando de esta manera el compromiso con el proyecto de un sistema intemacional de comercio libre y abierto.

Esto significa que el APEC no constituirá un "bloque económico», cerrado al exterior, proteccionista. A diferencia de la Unión Europea por ejemplo, no dará incentivos especiales a alguna región en particular, ni tamspoco tendrá programas especiales para dęfender alguna industria o sector común (ejemplo, la industria aeronáulica o política del sector agrícola de la Unión Europea).

Lo anterjor se sustenta en el APEC en el luecho de que la integración económica entre sus miembros no es guiada por los gobiernos sino por el sector privado. Integración autónoma que ocurre no por el gobierno sino a veces a pesar de los gobiemos. Las empresas privadas se mueven libremente en la región buscando el máximo beneficio, y de esta forma jutegran más las economías. 


\section{Evolución del APEC.-}

El APEC fue creado en 1989 a iniciativa del Primer Ministro Hawke de Australia, y su primera reunión tuvo lugar en Camberra, en ese mismo país, en uoviembre de ese año. Las primeras reuuiones fueron de carácter Ministerial, especialmente de los representantes del área económica.

Los miembros iniciales del APEC fueron 12 economías: Brunei, Indonesia, Malasia, Filipinas, Singapur. Tailandia, EE.UU. Canadá, Australia, Nueva Zelandia, Corea del Sur y Japón.

La segunda reunión en 1990 fue en Singapur, la tercera reunión de 1991 fue en Seúl, Corea del Sur, y aquí fueron admitidos China, Taiwán y Hong Kong, sumando 15 los miembros.

La cuarta reunión en 1992 fue en Bangkok, Tailandia, y la quinta reunión eu 1993, Seattle, EE.UU., y en esta reunión se admitió a México. Desde 1993 el APEC adquiere un carácter de primer nivel con las reuniones de jefes de Estado. En la sexta reunión en 1994 en Bogor, Indonesia, se acuerda la formación de un área de libre comercio en el 2020 para todas las economías y 10 años antes, el 2010 para las economías industrializadas. En esta reunión sc admitió a Papua Nueva Guinea y Chile.

En la séptima reunión de 1995 en Osaka, Japón, se fijan los criterios para empezar la liberalización de las economías. En la octava reunión en Manila, Filipinas, en 1996 se escogen los sectores a ser primeros liberalizados (el sector de telecomunicaciones a comienzos del año 2000). Aquí se adopta el famoso Manila Action Plan for APEC (MAPA) o Plan de Acción de Manila para el APEC, con el propósito de poner fechas a los programas de liberalización específicos a cada sector.

La reunión de Vancouver, Canadá, de 1997 fue la Novena reunión general del APEC y la 5ta. de Jefes de Estado. En esta reunión se vio especialmente la crisis financiera que viven los países asiáticos pero no se acordó nada específico sobre este tema, En esta reunión se acordó la incorporación desde 1998 del Perú, Vietnam y Rusia.

La última reunión del APEC, la 10ma. Reunión General y la 6ta. de Jefes de Estado se ha llevado a cabo en Kuala Lumpur, capital de Malasia, en Noviembre, específicamente los días 17 y 18 para la reunión de los Jefes de Estado. El Perí ha participado con Rusia y Vietnam por primera vez en esta Reunión, sumando así 21 miembros en total los integrantes del APEC.

\section{¿Por qué el Perú ingresó al APEC?}

Perú cumplió los requisitos para pertenecer a APEC que eran:

- Una economía en crecimiento y abierta al exterior. El Perí está mostrando desde 1990 un crecimiento de su economa y ha liberalizado su mercado en forma creciente.

- Crecientes relaciones comerciales con la región Asia - Pacífico. El Perú también desde 1990 ha incrementado sus relaciones comerciales con los países del Asia - Pacífico. Especialmente nuestro comercio con los países asiáticos se ha incrementado, al punto que en 1997 China fue nuestro 2do. mayor mercado de exportación, desplazando a Japón de este puesto.

- Crecientes relaciones diplomáticas y políticas. En este punto, el Perú desde 1990 ha mostrado una agresiva política de apertura diplomática y política hacia la región Asia Pacífico. Las visitas del presidente Fujimori a los países de la región, las visitas de dignatarios de esa región a nuestro país; la apertura de Embajadas y Consulados del Perú en esos países, la apertura de Embajadas y Consulados de esos países en el nuestro, es una muestra de ello.

- Apoyo unánime de los países del APEC para el ingreso. Perú contó con el fuerte apoyo de Japón y demás países del APEC. Perú, además, participaba ya en varios Grupos de Trabajo de APEC sin ser miembro, como en el Grupo de Pesquería, Turismo, y Energía.

\section{Beneficios (y costos) del ingreso del Perú} al APEC.-

- El beneficio inmediato es que el «status» del Perú, como país, al ser miembro del APEC, 
subirá en el concierto internacional. El pertenecer al APEC, «el club de los países ticos y de los que se encaminan a serlon es un gran honor. Perú podrá aprovechar esta imagen para poder seguir atrayendo inversión extranjera a nuestro país.

- Otro beneficio es la posibilidad de alcanzar un mayor comercio, mayor inversión, mayor cooperación con los países más grandes del mundo y de mayor crecimiento económico que pertenecen al APEC. Esto no será inmediato pero es una gran atracción de la pertenencia a este Foro. El año 2020 se ha fijado como meta para liberalizar el comercio y la inversión entre los países miembros. Este es una gran oportunidad que nuestro país debe aprovechar.

- Los costos se darán en la medida de que no seamos competitivos para sacar ventaja de un mayor comercio con los países del APEC. Los países asiáticos del APEC están entre los más competitivos del mundo en el sector de exportación de manufacturas. Tenemos que tomar esto como una oportunidad, como un desafió para ser más modernos y competitivos. De no ser así, el mayor comercio con los países del APEC se traducirá en mayores importaciones nuestras de esos países, y tendremos un mayor déficit comercial con esos países (en 1997 nuestro déficit con los 18 países del APEC representaba el $67 \%$ de nuestro deficit comercial total, especialmente por nuestro gran deficit con EE.UU.). Pero tenemos aún un superávit comercial con los países asiáticos del APEC pero este está disminuyendo (de hecho en la primera mitad de este año 1998 tenemos ya un déficit comercial con los países asiáticos del APEC).

\section{¿Qué debemos hacer para aprovechar nuestro ingreso al APEC?}

1. Prepararse en el área política-diplomática. Se ha avanzado mucho en esto y tenemos:

- Mayores acercamientos políticos. Ha habido visitas del Presidente Fujimori a la región asiática desde 1990.

Visitas de dignatarios asiáticos desde 1990.

Tenemos la participación del Perú en el Foro Parlamentario Asia - Pacífico (APPF)

- Acercamientos diplomáticos desde 1990. Ha habido aperturas de Embajadas y Consulados desde 1990.

De Asia en el Perú: Se ha establecido la Embajada de Malasia, un Consulado de Indonesia, aparte de las existentes Embajadas de Japón, Corea del Sur, China, Australia, y la Oficina Representativa de Taiwan.

Del Perú en Asia: Había tradicionalmente Embajadas del Perú solo en Japón, Corea del Sur, China y Australia.

Se han abierto nuevas Embajadas en Tailandia, Malasia, Indonesia y Singapur, Misiones Consulares en Filipinas y Nueva Zelandia.

Tenemos también Representaciones Comerciales en Taipei, y concurrencia en Vietnam (desde Ia Embajada de Tailandia), Brunei Darussalam, Fiji y Papua Nueva Guinea.

\section{Prepararse en el área} económico-empresarial

Nuestro comercio con Asia ha crecido desde 1990 ,

Pero seguimos exportando principalmente materias primas y hay el peligro de un surgimiento de un déficic con la región asiática.

Necesitamos una mayor participación en el PBEC (Consejo Económico de la Cuenca del Pacifico).

Creado en 1967, el PBEC es un organismo que agrupa a empresarios de la región Asia - Pacífico, El Perú es miembro desde 1980, y en rotal participan 1100 miembros (compañías) de más de 22 economías.

Nuestros ęmpresarios deben preparase para competir. Pero deben ser apoyados por el gobierno. Debe haber un trabajo conjunto, como lo demuestra la experiencia de los parses asiáticos (y Chile también). 


\section{Prepararse en el área académica}

Debemos tener una mayor participación en el PECC (Consejo de Cooperación Económica del Pacifico). Organismo tripartito de funcionarios de gobierno, académicos y empresarios. Creado en 1980, el Perú está presente desde
1990, agrupa a 23 economías. Para tener mayor participación en el PECC se necesita formar expertos en el área Asia - Pacífico. Hay que conocer Asia. Incentivar los estudios sobre Asia y los países asiáticos. Lamentablemente poco se está haciendo en esto.

\section{CONCLUSIONES}

El ingreso del Perú al APEC es beneficioso para nuestro país. Es un triunfo personal del Presidente Fujimori, que desde 1990 ha impulsado un mayor acercamiento de nuestro país a la región Asia - Pacífico, y que desde este noviembre de 1998 se reunirá anualmente con los lideres más connotados del mundo como son los de EE.UU., Japón, Rusia, China y otros.

Para sacar provecho a nuestra pertenencia al APEC, y para estar preparados para un régimen libre de comercio e inversiones a] año 2020 en la región, nuestra economía y nuestra industria tiene que ser competitiva. En esto la tarea es de los empresarios privados, que deben mirar sobre todo a Asia, donde están las grandes oportunidades de negocios. Este debe ser un trabajo conjunto de los empresarios privados con el gobiemo. Chile, que ingreso al APEC en 1995, se preparo desde la década del 80 para incursionar en Asia. Nos toca seguir el ejemplo de Chile, un país latinoamericano que aumento sus exportaciones, y diversificó sus exportaciones a Asia, gracias al trabajo de-sus empresarios privados, que unieron esfuerzos entre ellos, y donde el gobierno, a través de instituciones como Fundación Chile y ProChile (instituciones parecidas a Prompex y Promperú) ayudaron a través de la promoción de exportaciones a incursionar sus empresas en los países asiáticos.

\section{Explicaciones de los cuadros sobre el APEC y las relaciones económicas del Perú con las economías miembros de ese Foro}

Nota: De acuerdo con la terminología usada en el APEC, los miembros del APEC son llamados economías miembros (evitándose usar el término país). Asimismo, Hong Kong es llamado generalmente Hong Kong, China (indicando que Hong Kong ya es parte de China, aunque participa con su propia representación en las reuniones del APEC), y Taiwan, es llamada Taipei, China.

\section{Cuadro 26. Indicadores básicos de los países miembros del APEC, 1996}

su área geográfica, población, tamaño de su economía medido por su Producto Nacional Bruto (PNB), y el PNB per capita. Nos permite ver la diversidad de economfas que conforman el APEC, desde los más ricos e industrializados como EE.UU. y Japón, hasta las economías emergentes como China (y Vietnam).

\section{Cuadro 27. Monto del comercio exterior en las economías miembros del APEC, 1996.}


portaciones en 1996 para cada una de las economúas miembros del APEC.

Cuadro 28. Incremento del monto de las exportaciones en lus economías miembros del APEC entre 1990 y 1996.

Mucstra como el monto de las exportaciones ha crecido en gran proporción para todos y cada uno de las economias miembros del APEC. Casi todos han más que duplicado el monto de sus exportaciones entre 1990 y 1996.

\section{Cuadro 29. Porcentaje del Comercio Intra - APEC entre 1993 y 1996}

Muestra como el comercio (exportaciones más importaciones) entre las economías miembros del APEC, esto es el comercio Intra - APEC, es cada vez más importante para cada uuo de ellos. Por ejemplo en 1993 el 84\% del comercio de Canadá fue con otras economías del APEC, y en 1996 esre porcentaje subió al $87 \%$. En suma, las economías miembros del APEC comercian cada vez nás entre sí.

\section{Cuadro 30. Flujos de Inversión Extranjera Directa en las economias miembros del APEC entre 1991 y 1995.}

EL APEC busca crear el año 2020 un área de libre comercio e inversiones entre sus miembros. La inversión extranjera directa (IED) ha cumplido un rol muy importante en el desartollo de las economías miembros del APEC, y ha experimentado un gran crecimiento entre 1991 y 1995. Lo sorprendente es que la inversión se ha incrementado no solo hacia las economías del APEC (IED hacia) sino desde las economías del APEC (IED desde). Por ejemplo, China no sólo ha recibido una gran cantidad de inversión extranjera directa entre esos años (ver por ejemplo
IED hacia China que pasó de un flujo de 4,366 millones de dólares en 1991 a 37,500 millones en 1995), sino que se ha convertido en un gran inversor en el extranjero. Por ejemplo, en IED desde China, el gigante asiático incrementó sus inversiones en el extranjero desde 913 millones de dólares en 1991 a 3,467 millones en 1995.

\section{Cuadro 31. Stock de la Inversín Extranjera Directa como \% del PBI, entre 1980 y 1995}

Confirmando el cada vez más imporante rol de la Inversión Extranjera Directa en las economías miembros del APEC, esta IED como porcentaje de su Producto Bruta lnterno (PBI) se ha incrementado grandemente entre los años 1980 y 1995. Otra vez el caso de China es sorprendente, pues en 1980 la IED total (el stock en ese año) era casi inexistente en China, pero en 1995 ésta llegó a representar el $18.2 \%$ de su PBl. (ver IED hacia China en 1980 y 1995 por ejemplo).

\section{Cuadro 32. Perú: Intercambio Comercial por principales bloques económicas}

Indica qne para el Perú el APEC representa cl bloque económico más importante para su comercio exterior.

\section{Cuadro 33. Perú: Comercio por principales países}

Muestra que en el ranking de nuestros principales socios en el comercio exterior, varios países del APEC están en los primeros lugares.

\section{Cuadro 34. Perú: Principales paises del APEC destino de las exportaciones, 1997.}

Muestra que para el Perú los países del APEC representaron en 1997 el $51.08 \%$ de total de nuestras exportaciones. Los países asiálicos del 
APEC representaron el $22.13 \%$ del total.

\section{Cuadro 35. Perú: Principales países del APEC origen de las importaciones, 1997.}

Muestra que para el Perú los países del APEC representaron en 1997 el $51.87 \%$ del origen de todas nuestras importaciones. Las importaciones desde los países asiáticos del APEC representaron solo el $14.87 \%$ del total.

Cuadro 36. Perú: Principales países del APEC destino de las exportaciones, enero a junio de 1998.

Debido a la crisis asiática que baja la demanda por nuestros productos desde los países asiáticos (y la reducción notable de las exportaciones de harina de pescado, mucha de la cual iba a esos países), nuestras exportaciones a los países asiáticos miembros del APEC cayeron notablemente y llegaron a representar solo el $12.79 \%$ del total en la primera mitad de este año 1998, en comparación al 22.13\% del total en el año 1997 (ver cuadro 9)
Cuadro 37. Perú: Principales países del APEC origen de las importaciones, enero a junio de 1998.

Nuestras importaciones desde los países del APEC y desde los países asiáticos aumentaron ligeramente en la primera mitad de este año 1998.

\section{Cuadro 38. Perú: Inversión desde los países del APEC}

Muestra que si bien la inversión extranjera directa en nuestro país ha aumentado grandemente entre 1990 y julio de 1998, la inversión desde los países del APEC es aún pequeña, explicada principalmente por la inversión de un solo país, EE.UU. La inversión desde los países asiáticos del APEC es ínfima (solo $2.43 \%$ del total).

Los Cuadros 39 al 41 muestran algunos indicadores económicos de los principales países asiáticos del APEC, que sin duda se convertirán en nuestros principales competidores en este Foro, a pesar de la seria crisis económica que atraviesan en estos momentos casi todos ellos (como se ve en el cuadro 40 ). 


\section{CUADRO 26}

\section{INDICADORES BÁSICOS DE LAS ECONOMIAS MIEMBROS DEL APEC 1996}

\begin{tabular}{|c|c|c|c|c|}
\hline 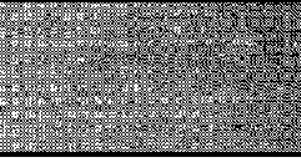 & 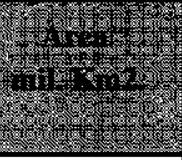 & 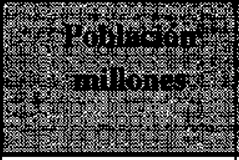 & 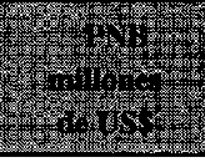 & S \\
\hline \multicolumn{5}{|l|}{ República } \\
\hline Popular China & 9,561 & $1,232.08$ & 906,100 & 750 \\
\hline Indonesia & 1,905 & 198.34 & 213.400 & 1,080 \\
\hline Papua Nueva Guinea & 463 & 4.40 & 4,976 & 1,160 \\
\hline Filipinas & 300 & 71.90 & 83,300 & 1,160 \\
\hline Tailandia & 513 & 60.00 & 177,500 & 2,960 \\
\hline Méxieo & 1,958 & 96.58 & 341,700 & 3,670 \\
\hline Malasia & 330 & 20.57 & 89,800 & 4,370 \\
\hline Chile & 757 & 14.42 & 70,100 & 4,860 \\
\hline Corea del Sur & 99 & 45.54 & 483,100 & 10,610 \\
\hline Taiwán & 36 & 21.47 & 275,144 & 12,872 \\
\hline Nueva Zelandia & 271 & 3.57 & 57,100 & 15,720 \\
\hline Brunei & 5.7 & 0.30 & 4,850 & 17,039 \\
\hline Australia & 7,713 & 18.31 & 367,800 & 18,720 \\
\hline Canadá & 9,976 & 29.97 & 569,900 & 19,020 \\
\hline Hong Kong & 1 & 6.31 & 153,300 & 24,290 \\
\hline Singapur & 0.65 & 3.74 & 93,000 & 30,500 \\
\hline EE.UU. & 9,364 & 266.56 & $7,433,500$ & 28,020 \\
\hline Japón & 378 & 125.26 & $5,149,200$ & 40,940 \\
\hline \multicolumn{5}{|l|}{ Miembros designados: } \\
\hline Vietnam & 325 & 75.00 & 21,900 & 290 \\
\hline \multicolumn{5}{|l|}{ Federación de } \\
\hline Rusia & 16,889 & 148.00 & 356,000 & 2,410 \\
\hline Perú & 1,280 & 24.00 & 58,700 & 2,420 \\
\hline
\end{tabular}

Fueute: APEC - Key Indicators of Members Economies

Tomado de la página web de APEC: www.apec.seg.org.sg/ 


\section{CUADRO 27}

MONTO DEL COMERCIO EXTERIOR EN LAS ECONOMIAS MIEMBROS DEL APEC (Exportaciones e Importaciones en 1996 - millones de dólares)

\begin{tabular}{|c|c|c|}
\hline W & (3) & (2) \\
\hline EE.UU. & 822,025 & 625,073 \\
\hline Japón & 336,000 & 443,100 \\
\hline Canadá & 174,962 & 201,636 \\
\hline Hong Kong & 198,560 & 180.745 \\
\hline China & 138,944 & 151,197 \\
\hline Corea del Sur & 150,676 & 130,346 \\
\hline Singapur & 125,016 & 131,340 \\
\hline Taiwán & 102,400 & 115,900 \\
\hline México & 61,163 & 79,543 \\
\hline Malasia & 78,418 & 78,254 \\
\hline Australia & 65,428 & 60,299 \\
\hline Tailandia & 71,843 & 55,526 \\
\hline Indonesia & 42,929 & 49,814 \\
\hline Filipinas & 34,122 & 20,417 \\
\hline Chile & 17,828 & 15,353 \\
\hline Nueva Zelandia & 14,725 & 14,360 \\
\hline Brunei & 1,195 & 2,273 \\
\hline Papua Nueva Guinea & 1,500 & 2,700 \\
\hline \multicolumn{3}{|l|}{ Miembros designados: } \\
\hline Vietnam & 8,155 & 5,499 \\
\hline \multicolumn{3}{|l|}{ Federaeión de } \\
\hline Rusia & 60,916 & 81,137 \\
\hline Perú & 9,224 & 5,575 \\
\hline
\end{tabular}

Fuente: APEC - Key Indicators of Members Economies Tomado de la pagina web de APEC: www.apec.seg.org.sg/ 


\section{CUADRO 28}

INCREMENTO DEL MONTO DE LAS EXPORTACIONES EN LAS ECONOMÍAS

DEL APEC, 1990 Y 1996 - MLLONES DE DÓLARES

\begin{tabular}{|l|c|c|}
\hline EE.UU. & (1) & (1) \\
\hline Japón & 371,466 & 625,073 \\
Canadá & 286,768 & 443,100 \\
Hong Kong & 125,056 & 201,636 \\
China & 29,002 & 180.745 \\
Corea del Sur & 62,091 & 151,197 \\
Singapur & 64,837 & 130,346 \\
Taiwán & 52,627 & 131,340 \\
Méxica & 67,025 & 115,900 \\
Malasia & 26,714 & 79,543 \\
Australia & 29,409 & 78,254 \\
Tailandia & 35,973 & 60,299 \\
Indonesia & 23,002 & 55,526 \\
Filipinas & 25,553 & 49,814 \\
Chile & 8,681 & 20,417 \\
Nueva Zelandia & 8,579 & 15,353 \\
Brunei & 9.045 & 14,360 \\
Papua Nueva Guinea & sd & 2,273 \\
\hline & sd & 2,700 \\
\hline
\end{tabular}

Fuente: «World Development Report», del World Bank, 1992 y de APEC

- «Key Indicators of Members Economies»

Tomado de la página web de APEC: www.apec.seg.org.sg/ sd: sin datos 


\section{CUADRO 29}

PORCENTAJES DEL COMERCIO* INTRA - APEC: 1993 Y 1996

\begin{tabular}{|l|c|c|}
\hline Hemisferio Occidental & & \\
Canadá & 84 & 87 \\
Chile & 48 & 50 \\
México & 84 & 88 \\
EE.UU. & 64 & 65 \\
Noreste Asiático & & \\
China & 71 & 74 \\
Hong Kong, China & 80 & 80 \\
Japón & 69 & 71 \\
Corea del Sur & 69 & 67 \\
Taipei, China & 75 & 74 \\
Sudeste Asiático & & \\
Brunei Darussalam & 87 & 90 \\
Indonesia & 77 & 75 \\
Malasia & 80 & 67 \\
Filipinas & 76 & 79 \\
Singapur & 74 & 74 \\
Tailandia & 69 & 70 \\
Oceanía & & 71 \\
Australia & 73 & 60 \\
Nueva Zelandia & 65 & $5 d$ \\
Papua Nueva Guinea & sd & \\
APEC & & 71 \\
\hline
\end{tabular}

Fuente: «1997 APEC Economic Outlook», Economic Committee Asia-Pacific Economic Cooperation, noviembre de 1997.

* Exportaciones más Importaciones

sd: $\sin$ datos 
CUADRO 30

\section{FLUJOS DE INVERSIÓN EXTRANJERA DIRECTA (IED) EN LAS ECONOMIAS MIEMBROS DEL APEC, 1991 Y 1995.}

(millones de US\$)

\begin{tabular}{|c|c|c|c|c|}
\hline (for) & $\frac{3}{3031}$ & $\frac{17}{10068 x}$ & $\frac{2.100}{1091}$ & 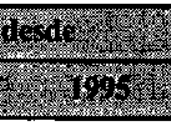 \\
\hline \multicolumn{5}{|l|}{ Hemisferio Occidental } \\
\hline Canadá & 2,740 & 11,182 & 5,655 & 4,782 \\
\hline Chile & 523 & 3,021 & 123 & 644 \\
\hline México & s.d. & s.d. & 167 & 597 \\
\hline EE.UU. & 22,020 & 60,236 & 33,456 & 95,509 \\
\hline \multicolumn{5}{|l|}{ Noreste Asiático } \\
\hline China & 4,366 & 37,500 & 913 & 3,467 \\
\hline Hong Kong, China & 538 & 2,100 & 2,825 & 25,000 \\
\hline Japón & 1,730 & 39 & 30,700 & 22,700 \\
\hline Corea del Sur & 1,180 & 1,500 & 1,500 & 3,000 \\
\hline Taipei, China & 1,271 & 1,470 & 1,854 & 3,822 \\
\hline \multicolumn{5}{|l|}{ Sudeste Asiático } \\
\hline Brunei Darussalam & 1 & 7 & - & - \\
\hline Indonesia & 1,482 & 4,500 & 13 & 12 \\
\hline Malasia & 3,998 & 5,800 & 389 & 2,575 \\
\hline Filipinas & 544 & 1,500 & -26 & 9 \\
\hline Singapur & 4,879 & 5,302 & 1,024 & 2,799 \\
\hline Tailandia & 2,014 & 2,300 & 167 & 904 \\
\hline \multicolumn{5}{|l|}{ Oceanía } \\
\hline Australia & 4,903 & 13,094 & 3,126 & 5,372 \\
\hline Nueva Zelanda & 1,698 & 2,483 & 1,475 & 1,310 \\
\hline Papua Nueva Guinea & 203 & 15 & - & - \\
\hline
\end{tabular}

Fuente: UNCTAD: «World Investment Report 1997», tomado de «1997 APEC Economic Outlook», Economic Committee Asia - Pacific Economic Cooperation, noviembre de 1997.

* Nota del autor: Los datos de IED desde Japón son tomados de otra fuente. s.d.= sin datos 
(en \%)

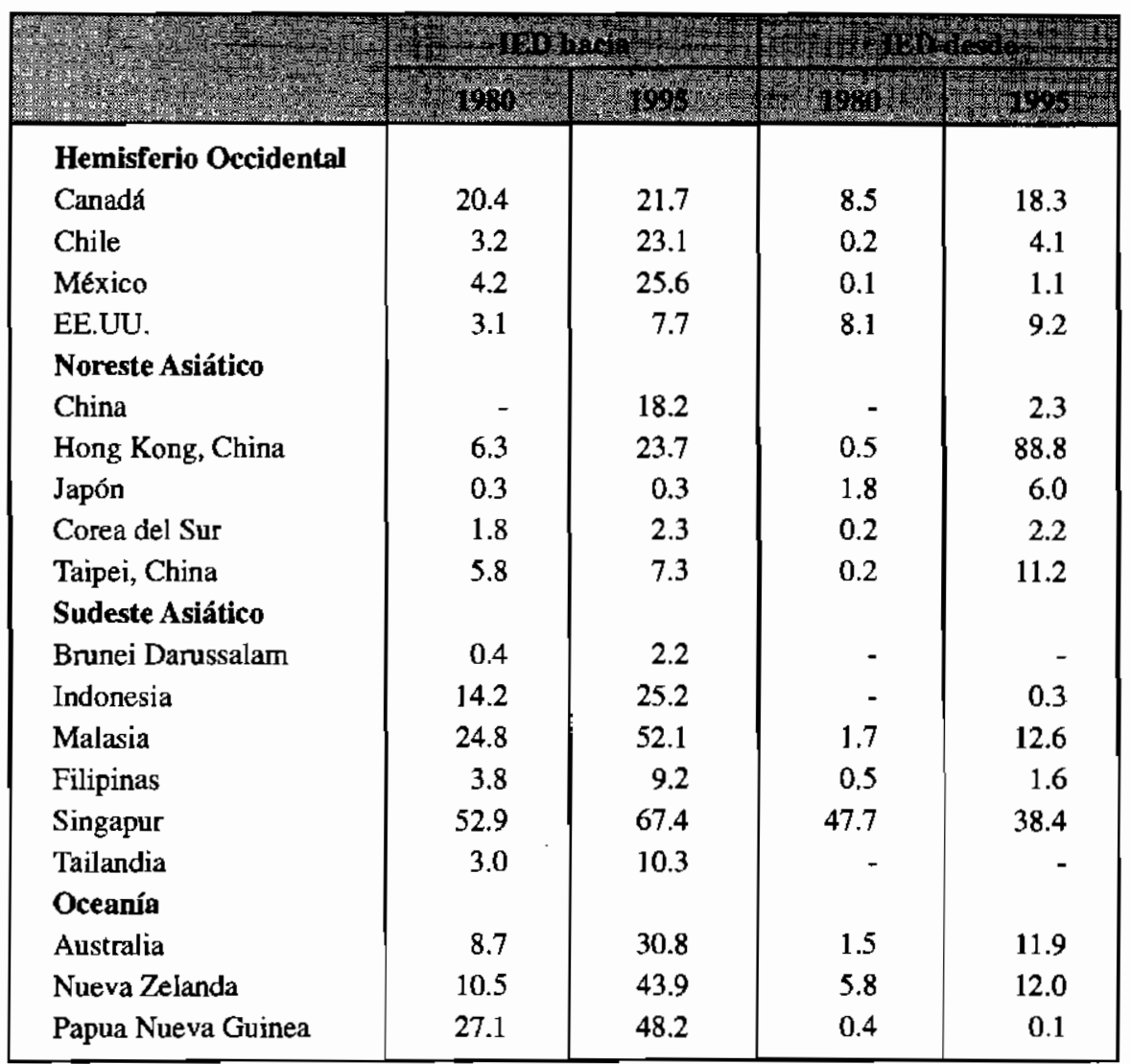

Fuente: UNCTAD: «World Investment Report 1997», tomado de «1997 APEC Economic Outlook», Economic Committee Asia - Pacific Economic Cooperation, noviembre de 1997. 


\section{CUADRO 32}

\section{PERÚ: INTERCAMBIO COMERCIAL POR PRINCIPALES BLOQUES ECONÓMICOS 1997}

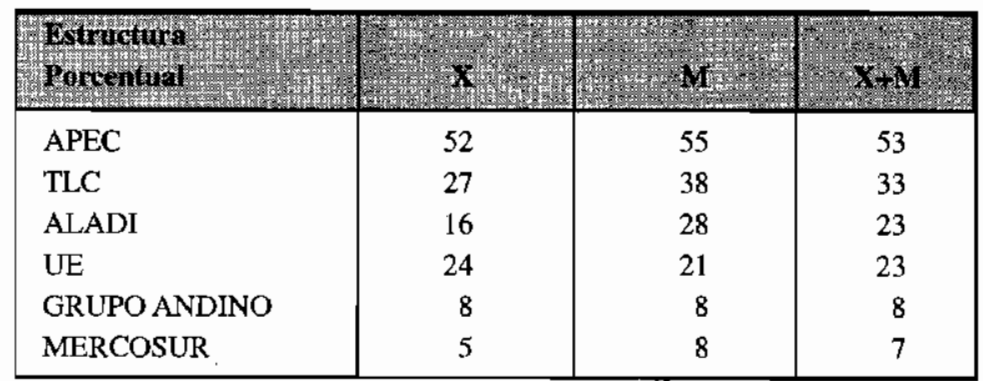

$\mathbf{X}$ : Exportaciones

M: Importaciones

TLC: Tratado de Libre Comercio de América del Norte

ALADI: Asociación Latinoamericana de Integración

Fuente: Banco Central de Reserva, Memoria 1997

\section{CUADRO 33}

PERÚ: COMERCIO POR PRINCIPALES PAÍSES

(Estructura porcentual)

\begin{tabular}{|c|c|c|c|c|c|c|c|c|c|c|c|c|}
\hline \multirow{2}{*}{ 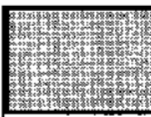 } & \multicolumn{4}{|c|}{ Bxpontacones } & \multicolumn{4}{|c|}{ empertaciones } & \multicolumn{4}{|c|}{$x+14$} \\
\hline & 1994 & 1095 & 109 & 1927 & 69 & 1095 & 1906 & 109 & $10 \%$ & 19o6: & 106 & 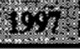 \\
\hline EE.UU. & 16.1 & 17.2 & 19.9 & 23.7 & 28.8 & 27.2 & 30.7 & $3 I .9$ & 23.1 & 23.0 & 26.0 & 28.2 \\
\hline España & 1.7 & 2.2 & 2.4 & 2.3 & 1.3 & 4.2 & 5.7 & 8.5 & 1.5 & 3.3 & 4.3 & 5.7 \\
\hline Japón & 10.4 & 9.1 & 6.7 & 7.1 & 6.7 & 5.1 & 3.7 & 4.0 & 8.4 & 6.8 & 5.0 & 5.4 \\
\hline Alemania & 6.2 & 6.0 & 5.2 & 5.7 & 4.6 & 3.8 & 3.9 & 3.6 & 5.3 & 4.8 & 4.4 & 4.6 \\
\hline China & 6.3 & 6.4 & 7.2 & 7.3 & 1.2 & 2.1 & 1.1 & 1.4 & 3.5 & 3.9 & 3.8 & 4.1 \\
\hline Brasi] & 4.0 & 3.6 & 4.1 & 3.8 & 6.4 & 5.4 & 4.2 & 4.1 & 5.3 & 4.7 & 4.2 & 4.0 \\
\hline Chile & 1.9 & 2.8 & 2.1 & 2.0 & 7.7 & 7.6 & 5.7 & 5.6 & 5.1 & 5.6 & 4.1 & 3.9 \\
\hline Suiza & 1.2 & 3.3 & 5.0 & 6.1 & 1.2 & 0.8 & 0.8 & 1.1 & 1.2 & 1.8 & 2.6 & 3.4 \\
\hline Venezuela & 1.8 & 3.0 & 2.2 & 2.1 & 2.6 & 4.5 & 5.8 & 4.4 & 2.3 & 3.9 & 4.2 & 3.4 \\
\hline Colombia & 2.2 & 2.2 & 2.1 & 2.3 & 4.4 & 7.8 & 7.3 & 4.2 & 3.4 & 5.4 & 5.0 & 3.4 \\
\hline Italia & 4.4 & 4.5 & 3.4 & 3.4 & 2.8 & 2.4 & 2.2 & 2.4 & 3.5 & 3.2 & 2.7 & 2.8 \\
\hline Reino & & & & & & & & & & & & \\
\hline Unido & 8.9 & 7.4 & 7.3 & 4.4 & 1.3 & 1.3 & 1.3 & 1.3 & 4.7 & 3.9 & 3.9 & 2.7 \\
\hline México & 3.7 & 1.7 & 1.6 & 1.7 & 2.9 & 2.8 & 2.8 & 3.2 & 3.3 & 2.3 & 2.3 & 2.5 \\
\hline Resto & 31.7 & 30.6 & 30.8 & 28.1 & 25.5 & 25.1 & 24.8 & 24.3 & 29.9 & 27.4 & 27.5 & 25.9 \\
\hline Total & 100.0 & 100.0 & 100.0 & 100.0 & 100.0 & 100.0 & 100.0 & 100 & 100.0 & 100.0 & 100.0 & 100. \\
\hline
\end{tabular}

$\mathbf{X}$ : Exportaciones

M: Importaciones

Fuente: Banco Central de Reserva, Memoria 1996, 1997 


\section{Cuadro 34}

Perú: Principales países del APEC destino de las exportaciones

(miles de dólares - valor fob)

Enero-diciembre 1997

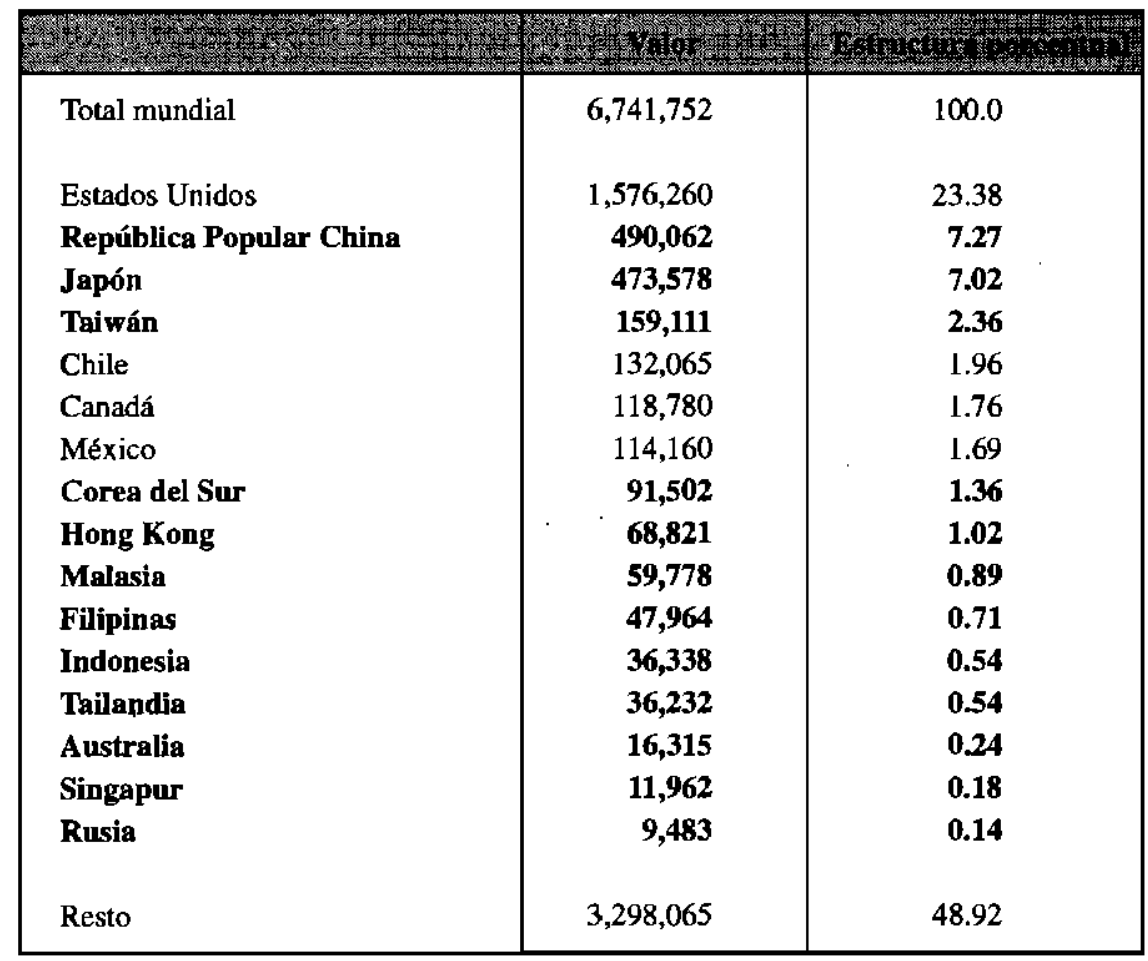

Fuente: Aduanas del Perí, Total exportaciones a los países del APEC: $51.08 \%$

Total exportaciones a los países asiáticos: $22.13 \%$ 


\section{CUADRO 35}

PERÚ: PRINCIPALES PAÍSES DEL APEC ORIGEN DE LAS IMPORTACIONES

(miles de dólares- valor fob)

Enero-diciembre 1997

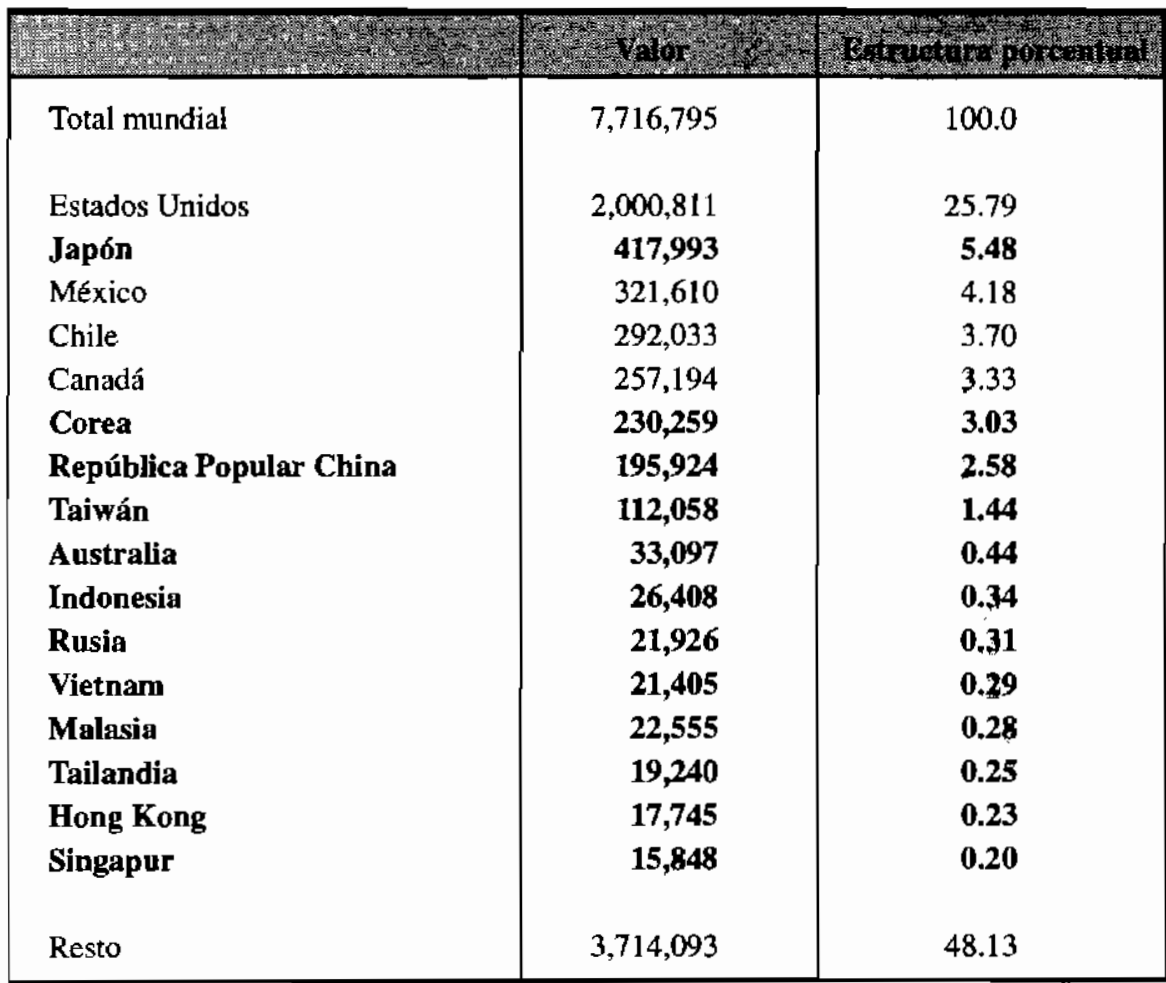

Fuente: Aduanas del Perú

Total importaciones de los paises del APEC: $51.87 \%$

Total importaciones de los países asiáticos: $14.87 \%$ 


\section{CUADRO 36}

PERÚ: PRINCIPALES PAÍSES DEL APEC DESTINO DE LAS EXPORTACIONES (miles de dólares - valor fob)

Enero - Junio de 1998

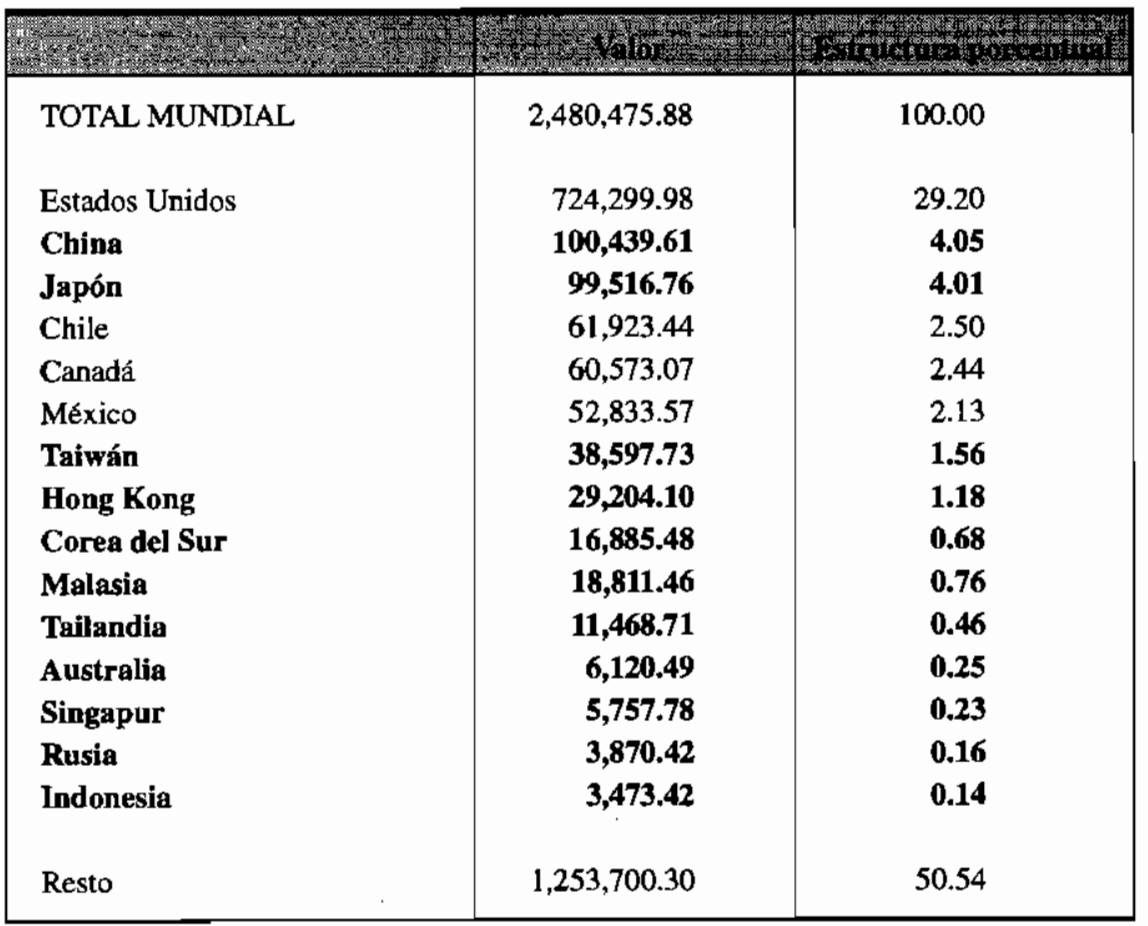

Fuente: Aduanas del Perú

Total exportaciones a los países del APEC: $49.46 \%$

Total exportaciones a los países asiáticos: $12.79 \%$ 


\section{CUADRO 37}

PERÚ: PRINCIPALES PAÍSES DEL APEC ORIGEN DE LAS IMPORTACIONES (miles de dólares- valor cif)

Enero - junio de 1998

\begin{tabular}{|c|c|c|}
\hline (3) & W. & 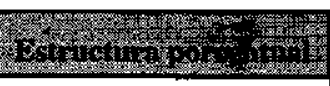 \\
\hline TOTAL MUNDIAL & $4,238,053.13$ & 100.00 \\
\hline Estados Unidos & $1,117,613.85$ & 26.37 \\
\hline Japón & $259,247.2 I$ & 6.12 \\
\hline Corea del Sur & $167,067.43$ & 3.94 \\
\hline México & $161,520.64$ & 3.81 \\
\hline Chile & $143,426.59$ & 3.38 \\
\hline Canadá & $115,891.89$ & 2.73 \\
\hline China & $97,793.60$ & 2.31 \\
\hline Rusia & $49,917.18$ & 1.18 \\
\hline Taiwan & $48,342.15$ & 1.07 \\
\hline Nueva Zelanda & $\quad 31,985.95$ & 0.75 \\
\hline Malasia & $25,628.56$ & 0.60 \\
\hline Indonesia & $24,206.14$ & 0.57 \\
\hline Australia & $18,622.79$ & 0.44 \\
\hline Tailandia & $9,090.84$ & 0.21 \\
\hline Singapur & $8,871,61$ & 0.21 \\
\hline Hong Kong & $5,864,21$ & 0.14 \\
\hline Rcsto & $1,955,962.49$ & 46.15 \\
\hline
\end{tabular}

Fuente: Aduanas del Perú Total importaciones de los países del APEC: 53.85

Total importaciones de los países asiáticos: 15.17 


\section{CUADRO 38}

PERÚ: INVERSIÓN DESDE LOS PATSES DEL APEC STOCK DE INVERSIÓN EXTRANJERA DIRECTA SEGÚN PAÍS DE ORIGEN

(en millones de dólares)

(a fines de cada periodo)

\begin{tabular}{|l|r|r|r|}
\hline & 1991 & 31071028 & 0 \\
\hline EE.UU. & 619.51 & $1,522.98$ & 20.60 \\
Chile & .27 & 293.87 & 3.97 \\
China & $\mathbf{. 1 1}$ & $\mathbf{1 2 2 . 1 6}$ & $\mathbf{1 . 7 1}$ \\
Canadá & 49.67 & 128.73 & 1.71 \\
Japón & $\mathbf{3 7 . 6 4}$ & $\mathbf{4 4 . 1 4}$ & $\mathbf{0 . 5 9}$ \\
México & 0.12 & 10.20 & 0.14 \\
Corea & $\mathbf{0}$ & $\mathbf{7 . 8 4}$ & $\mathbf{0 . 1 1}$ \\
Nueva Zelandia & $\mathbf{0 . 1 3}$ & $\mathbf{3 . 5 0}$ & $\mathbf{0 . 0 4}$ \\
Australia & - & $\mathbf{2 . 0 1}$ & $\mathbf{0 . 0 3}$ \\
Rusia & $\mathbf{0 . 1 9}$ & $\mathbf{0 . 1 9}$ & - \\
Total general & $1,302.04$ & $7,400.89$ & 100.00 \\
Total países de APEC & & $2,135.42$ & 28.85 \\
Total países de Asia & & 179.84 & 2.43 \\
\hline
\end{tabular}

Fuente: CONITE, Boletín de julio de 1998 


\section{CUADRO 39}

PRINCIPALES INDICADORES DE LOS PAÍSES DEL ESTE ASIÁTICO

(1997)

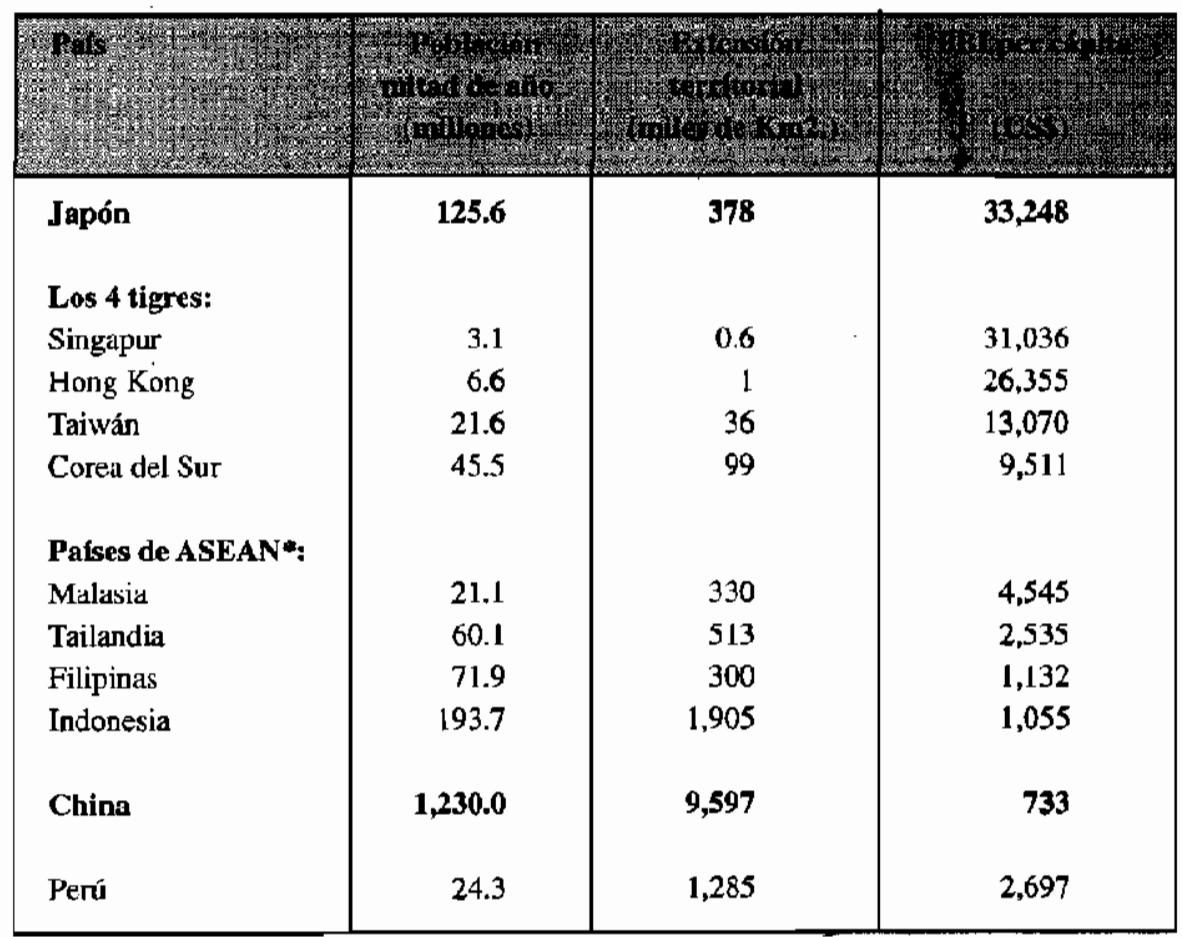

* ASEAN: Asociación de Naciones del Sudeste Asiático

Fuente: «Ajia Keizai 1998», de Keizai Kikakucho, Tokio. junio de 1998

Para el Perú: Memoria 1997, BCR. 


\section{CUADRO 40}

PRINCIPALES INDICADORES DE LOS PAISES DEL ESTE ASIATICO

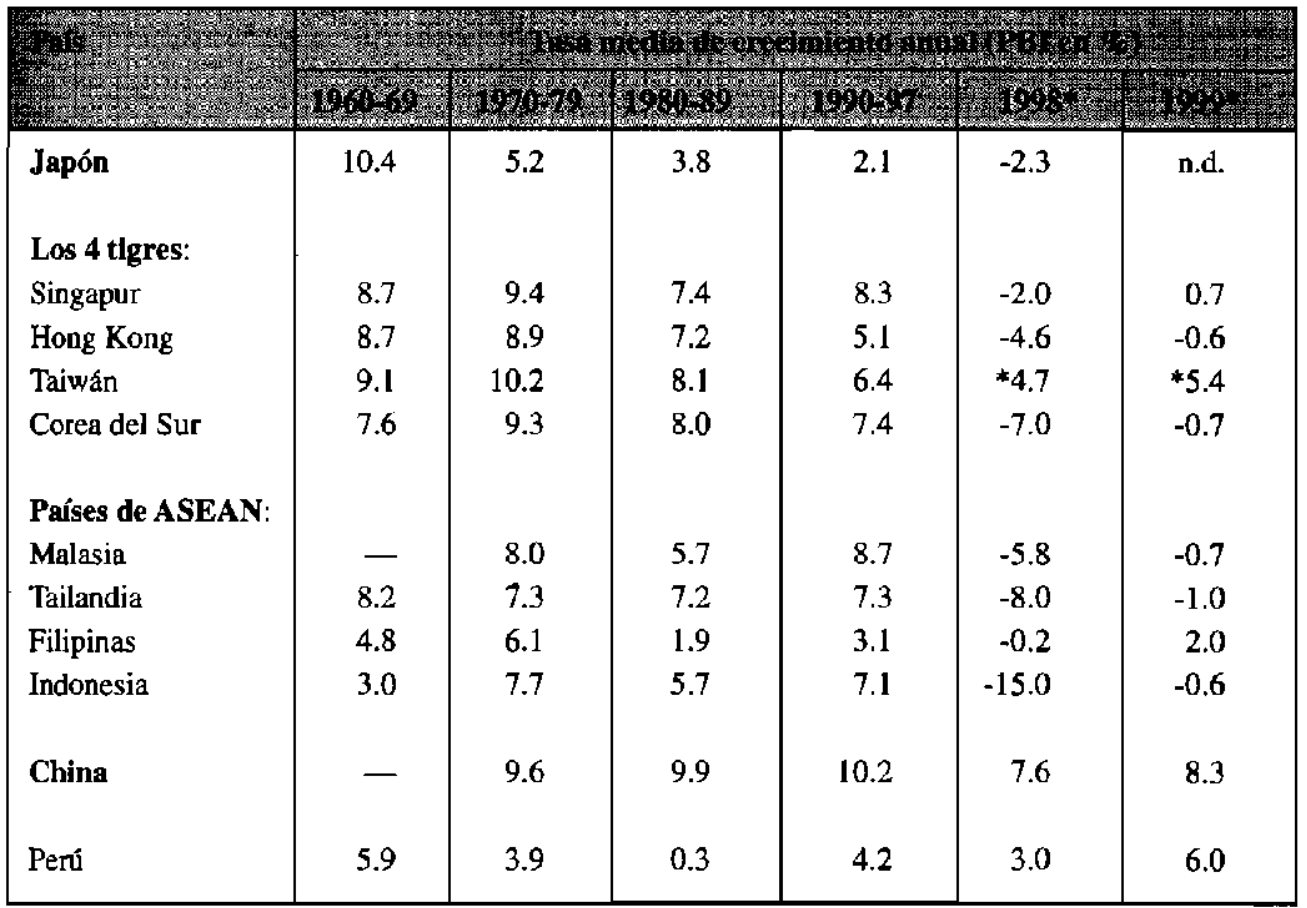

Fuente: «Ajia Keizai 1998» de Keizai Kikakucho, Tokio, junio de 1998.

* proyectado de la revista sernanal «Far Eastern Economic Review» de Hong Kong del 15 de octubre de 1998.

para el Perú: Memoria 1997, BCR y otros. 


\section{CUADRO 41}

PRINCIPALES INDICADORES DE LOS PAISES DEL ESTE ASLATICO

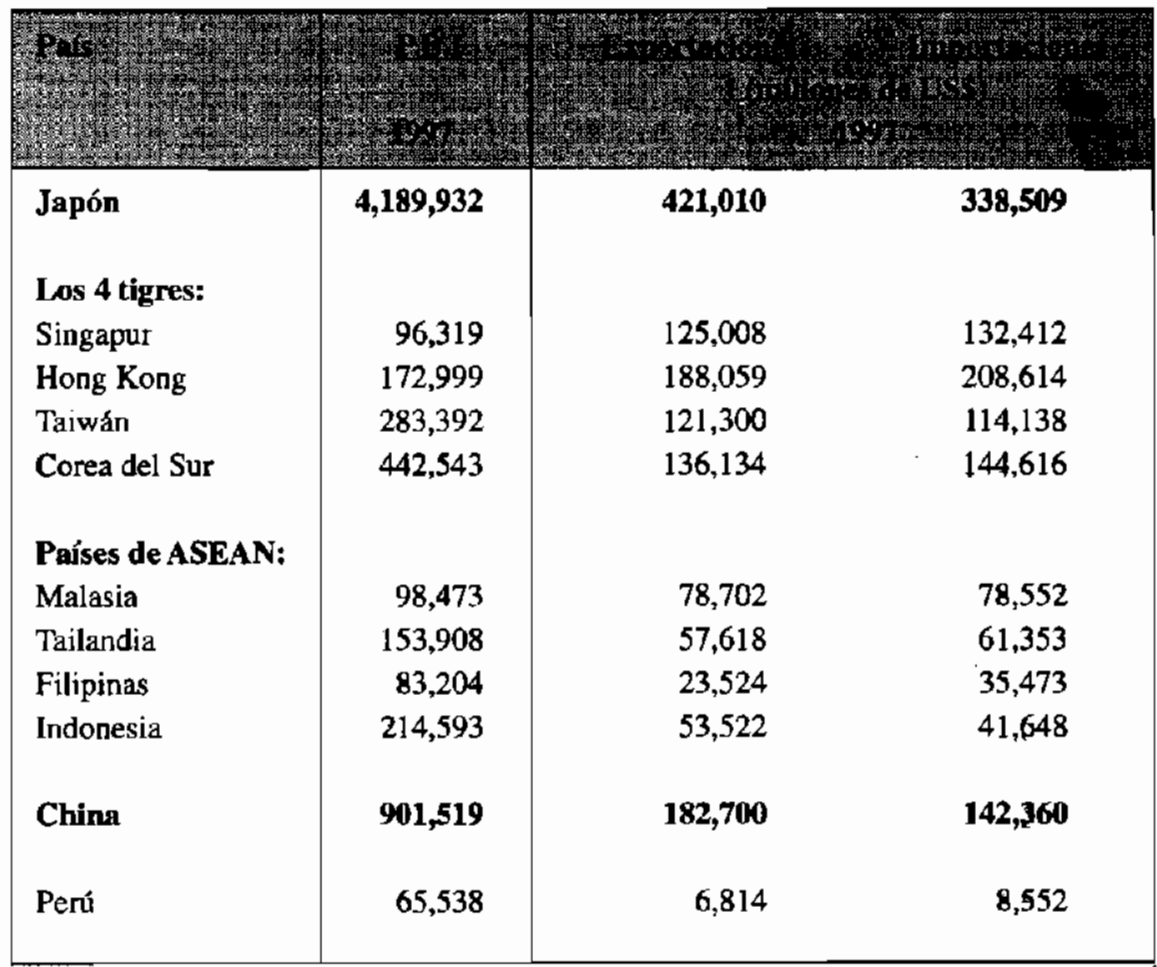

Fuente: «Ajia Keizai 1998» de Keizai Kikakucho, Tokio, junio de 1998 para el Perú: Memoria 1997, BCR. 